\title{
Planlı Ekonomi Karşısında Hayek’te Hukukun Üstünlüğ̈̈i
}

\author{
The Rule of Law in Hayek Against The Planned Economy
}

\section{Erdoğan Keskin * (iD}

\section{öz}

Hukukun üstünlüğ̈̈, insan hak ve hürriyetlerinin korunabilmesi için en temel gerekliliklerden birisidir. Ancak eşitlik ve sosyal adalet söylemi ile hukukun üstünlüğü ihlal edilmekte; birey ve hürriyetleri görmezden gelinmektedir. Dolayısıyla siyasi iktidar tarafından ekonominin planlandığı ve bireyin toplum içerisinde yok sayıldığı bir düzen hürriyetlerle uyuşmamaktadır. Günümüzde de sosyal adalet ve eşitlik arzusuna ilave olarak salgın hastalıklar, terör ve milliyetçilik gibi etkenlerle planlamacılığa rağbet edilmesi tehlikesi hala çok tazedir. Biz de bu nedenlerle çalışmamızda Hayek'in görüşleri aracilığıyla hürriyetlerin önemini hatırlatmak istiyoruz.

Anahtar Kelimeler: Hukukun Üstünlüğü, Kolektivizm, Birey, Hürriyet

\section{ABSTRACT}

The rule of law is one of the most basic requirements for the protection of human rights and freedoms. However, the rule of law is violated on grounds of the equality and social justice discourse by which individuals and their freedoms are ignored. Therefore, a system in which the economy is planned by the political power and the individual is ignored in the society does not comply with freedoms. Today, in addition to the desire for social justice and equality, the danger of planning is still very new due to factors such as epidemics, terrorism and nationalism. For these reasons, we would like to remind the importance of freedoms through Hayek's views in our work.

Keywords: Rule of Law, Collectivism, Individual, Freedom

\section{GiRiş}

"İnsanlar hürriyet ile mutluluk arasında seçim yapmak zorundaydı ve büyük çoğunluk mutluluğu seçiyordu."

(George Orwell, 1984)

Hayek özellikle dönemin tehdidi olarak değerlendirdiği totaliter rejimler bağlamında planlamacılık ile hukukun üstünlüğü ilkesine ilişkin çalışmalar yapmıştır. Çalışmalarında hukukun üstünlüğü ve hürriyetlere dikkat çekmiştir. Zira ona göre iktisadi serbestliğin, dolayısıyla tercih hürriyetinin

\footnotetext{
* Araştırma Görevlisi, Erzincan Binali Yıldırım Üniversitesi Hukuk Fakültesi Anayasa Hukuku Anabilim Dalı
}

Sorumlu Yazar/Correspondence Author: Erdoğan Keskin

E-posta/E-mail: erdogan.keskin@erzincan.edu.tr

Geliş Tarihi/Received: $\quad$ x.x..2020

Kabul Tarihi/Accepted: $\quad$ x.x.2021 
olmadığ1 bir toplumda ne hukukun üstünlüğ̈̈nden ne de hürriyetlerden söz edilebilir. Zira planlamacılık devletin resmi hedefler pahasına bireyin amaç ve tercihlerini görmezden gelmesine neden olur. Oysa Hayek’e göre tercih hürriyetleri ile iktisadi hürriyetler bireysel hürriyetlerin teminatı ve kaynağıdır.

Hayek kolektivizmi ve planlamacılığı bir bütün olarak değerlendirir. O bu konuda, kolektivizmden planlamacılığın, diğer bir ifadeyle ekonomiye dair kararların merkezi bir organ tarafından alınmasının anlaşılabileceğini dile getirir. Kendisi planlamacılı̆̆ı bu anlamıyla kullanmayı tercih eder. Ancak planlamacılığın daha iyi anlaşılabilmesi için bu kavramı da ayrıca açıklar ${ }^{1}$. Dolayısıyla biz de yazarın kavramlara verdiği anlamları dikkate alarak bu kavramları kullanacağımızdan, kolektivizm ve planlamacılı̆̆ı yazarın tercihleri doğrultusunda ele alacağı.

Öte yandan bugün ekonomi başta olmak üzere bireylerin özerk alanlarına dahil meselelerin tamamen devlet kontrolüne girmesi ve planlanmasının pek olası olmadığı düşünülebilir. Ancak bu bir yanılgıdan ibarettir. Hele ki günümüzde klasik medya araçlarının tekelleşme ve siyasileşmesi tehlikesi bireyleri siyasi iktidarın manipülasyonuna açı hale getirmektedir. Dolayısıyla Hayek'in üzerinde durduğu tehlikeler, bugünün dünyasına uzak değildir. Diğer yandan Amerika’da sağlık sistemin Covid-19 salgını sürecinde başarılı bir performans sunamaması, ancak belli oranda parasal güce sahip kimselerin sağlık-bakım hizmetlerinden yararlanabilmesi, buna karşılık sosyal devlet anlayışının hâkim olduğu Almanya gibi devletlerde sağlık hizmetlerinin başarılı olması, geleceğin dünyasının "kendiliğinden düzen”e karşı, müdahaleci ve sosyal adaleti gözeten bir sisteme evrileceği tehlikesini akla getirmektedir. Ayrıca küresel terör tehlikesi, göçmen sorunları gibi nedenler, devletlerin hürriyetçi yaklaşım yerine daha otoriter yaklaşımları benimsemelerine; siyasi olarak kutuplaşmaların artması dünya çapında yeniden totaliterleşmeye ve hukukun araçsallaşmasına neden olabileceğinden hürriyet rejiminin tehlikede olduğu göz ardı edilmemelidir.

Bu bakımdan iktidarın hukukla sınırlandırılması ve kişinin değil, hukukun yönetiminin hür bir toplumun ihyası için kaçınılmaz olduğunun anlaşılması gerekir. Bunun için de benzer süreçleri yaşamış önemli bir filozofun görüşlerinin hatırlanması, adalet ve eşitlik söylemi altında totaliter devlete giden süreçte hürriyetin unutulmaması ve muhafaza edilmesi oldukça elzemdir. Bölgesel perspektifte de mesele oldukça hassastır. Milliyetçi ve paternalist devlet anlayışının yükselişe geçtiği 21. yüzyılın ilk çeyreğinin sonlarında, hukukla kuşatılmış devlet ve hürriyetle süslenmiş bir toplum özlemi, Hayek'in ortaya koyduğu fikirlerle hatırlanmalı ve merkezileşmiş ekonomi tehlikesine karşı durulmalıdır. Bu kapsamda çalışma, Hayek’in konuya ilişkin yaklaşımlarını ele alarak günümüze de ışık tutmayı amaçlamaktadır.

1 Friedrich v. Hayek, Kölelik Yolu, Çev. Turhan Feyzioğlu/Yıldıray Arsan/Atilla Yayla, 6. Bs., Liberte Yayınları, Ankara 2015, s. 60; Bkz. Friedrich A. Hayek, The Road to Serfdom, Routledge, London/New York 2006, s. 35-36. Ayrica yazar kolektivizmi, sosyalizmle birlikte ele alır. Kolektivizm için geçerli olan her meselenin sosyalizm için de geçerli olduğunu belirtir. Bkz. Hayek, The Road to Serfdom, s. 35. Bu çerçevede Marksist teori ve teorisyenlerin çalışmaları dikkatle incelendiği zaman, bireyin serbest gelişimi ve hürriyeti karşısında tamamen planlanmış bir toplum modelinin gerekleri üzerinde durulduğu açıkça görülecektir. İlgili teori hakkında ayrıca bkz. Oktay Uygun, Hukuk Teorileri, On İki Levha Yayıncılık, İstanbul 2017, s. 141-151. 


\section{PLANLAMACILIĞA GENEL BİR BAKIŞ}

\section{A. Genel Olarak Planlamacılık}

Genel manada planlamacılık, önceden belirlenen hedeflere ulaşmak adına kaynakların hedef doğrultusunda etkin biçimde kullanılmasıyla sonuç almaya yönelik girişim veya çaba olarak tarif edilebilir ${ }^{2}$. Diğer bir ifadeyle, bir karar almadan ve eyleme geçmeden önce düşünmek, tasarlamak ve öngörülerde bulunmak olarak anlaşılabilir ${ }^{3}$. Planlamacılık, devlet boyutunda ele alındığında ise toplumsal ve siyasi bir niteliğe bürünür. Bu yönüyle kavram, toplumsal gelişim ve değişimin kontrol edilebileceği ve yönlendirilebileceği esasına dayanır. Yani planlamacılık toplum mühendisliği modeli olarak görülebilir ${ }^{4}$. Çalışma boyunca planlamacılı̆̆ biz de devlet eliyle toplumun kontrol edilmesi ve belirli hedeflerle ilişkili olarak toplumun dizayn edilmesi anlamında kullanacă̆ı.

Bu bağlamda planlamacılık akılcılıkla, sosyal bilimlerin yanı sıra matematik ve mühendislik gibi bilimlerle yakından ilişki içerisindedir ${ }^{5}$. Söz konusu bilimlerle bilgiler, siyasi araçlara ve istatistiksel verilere dönüştürülür, aynı zamanda belirlenen hedeflerin rakamsal değerlerine ulaşılır ${ }^{6}$. Bu bir süreci kapsar. Planlama sürecinin esası ise toplumsal bazı hedeflerin belirlenmesi, hedefi gerçekleştirmeye yönelik tedbirlerin ve çalışmaların programlanmasıdır. Diğer bir ifadeyle süreç, geleceğe yönelik tahminlerin ve hedeflerin belirlenmesinden, bu doğrultuda da devletin istediği yönde müdahalede bulunarak olayların seyrini amaca sevk etmesinden ibarettir ${ }^{7}$.

Heywood farklı görünümleri olsa da genel olarak planlamacılığın iki özelliğe sahip olduğunu kabul eder. Ona göre, her planlamacılık amaçlı ve rasyonel bir faaliyettir. İlk olarak, bu faaliyetlerin açık ve tanımlanmış hedefleri içermeleri gerekir. İkinci olarak da sosyal ve iktisadi sorunların ancak insan aklıyla çözülebileceği esasına dayanır ${ }^{8}$. Öyleyse planlamacılık, eşitsizlik ve kaynakların yetersizliği gibi sorunlar karşısında, önceden belirlenen hedefler doğrultusunda kaynakların rasyonel olarak kullanımı ve dağıtımına dayanır 9 .

Kaynakların ve hedeflerin merkezi olarak planlanması da üretim, tüketim, ücretler, ticari faaliyet alanları gibi gerek iktisadi gerekse sosyal pek çok alanda kontrol kurulmasını gerektirir ${ }^{10}$. Bunun yanı

2 Cevdet Yılmaz, "Piyasa Ekonomilerinde Ulusal Planlama ve Çeşitli Planlama Yaklaşımları”, Amme İdaresi Dergisi, C. 32, S. 1, Y. 1999, s. 85.

3 Andrew Heywood, Siyaset Teorisine Giriş, Çev. Hızır Murat Köse, 8. Bs., Küre Yayınları, İstanbul 2017 , s. 400.

4 Alkan Soyak, “Türkiye’de İktisadi Planlama: DPT’ye ihtiyaç Var mı?”, Doğuş Üniversitesi Dergisi, C. 4, S. 2, Y. 2003, s. 168. Planlama kavramı TDK'da şu şekilde tanımlanmaktadır: "Hükûmet tarafından ulaşılacak amaçları belirleyen, tarım, ulaşım, sanayi vb. kesimlerdeki artışölçüsünü tespit eden ve uygulanması gerekli çareleri önceden gösteren ekonomik, sosyal programın belli süreler için hazırlanması işi.” Bkz. https://sozluk.gov.tr, (11.5.2020).

5 Yilmaz, s. 86.

6 Benzer yönde bkz. Yılmaz, s. 86.

7 Soyak, s. 87.

8 Heywood, Siyaset Teorisine Giriş, s. 400.

9 Bkz. Heywood, Siyaset Teorisine Giriş, s. 400; Ahmet Fatih Özkan, "Ekonomik Kamu Düzeni ve Ekonomik Kolluk Faaliyeti", Ankara Barosu Dergisi, S. 4, Y. 2009 (Güz), s. 79.

10 Heywood, Siyaset Teorisine Giriş, s. 400. 
sıra devlet teşkilatı ve uzmanlar kadrosu, özellikle bürokrasi ${ }^{11}$ ön plana çıkmaktadır ${ }^{12}$. Dolayısıyla devletin bir plan yapması ile toplum yararına olarak belirlenen hedeflere ulaşmak adına bireysel ve iktisadi alanlara müdahalede bulunması, bireyciliğe karşıt, kolektivizme ise uygun sosyal şartlar oluşturur.

\section{B. Hayek'e Göre Planlamacılık Bağlamında Bireycilik ve Kolektivizm}

Planlamacılık bireysel tercihler ve toplumsal katılım yerine daha çok uzmanların ekonomik verileri ve istatistikleri kullanmaları, bu yönde belirlediği hedefleri hayata geçirmeleri şeklinde ortaya çıkar ${ }^{13}$. Planlamacılığ́ savunanlar insan aklının her meseleyi çözebileceğine güvendikleri için ekonominin merkezi olarak önceden tasarlanmasını, ücretlerin adil dağıtımı ve ekonomik kalkınmanın tamamlanması için elzem görürler. Öte yandan bu kimseler, bireyciliğin bencillikle sıkı bir bağ içerisinde olduğunu düşündüklerinden liberalizmin temeli olan bireyciliği reddederler. Bununla birlikte Hayek ise bireycilikle bencillik - egoizm ${ }^{14}$ - arasında zorunlu bir bağ olmadığını belirtir ${ }^{15}$.

Hayek, bireyciliğin kişisel menfaat ve tercihlerin bireyin özerk alanına bırakılmasını egoizmle doğrudan ilişkili olarak görmediği gibi, bireyciliği de yalnızca bireysel hedefler ve menfaatlerle ilişkili görmez. Bireycilik, aile ve sosyal yaşamın gereklilikleri gibi birey-üstü kurumların varlığını dışlamaz. Ancak devlet kontrolünde bir toplumsal hareket yerine gönüllülük esasına dayanan sosyal kurumlarla ve lokal özerkliklerle uyumludur ${ }^{16}$. Bireycilik anlayışına göre birey; toplumsal ve sanatsal faaliyetler başta olmak üzere her türlü insani kazanımın da merkezinde yer alır ${ }^{17}$.

11 Bürokrasi merkezi otoritenin işleyişi ve kararların uygulanması bakımından önemli bir konuma sahiptir. Bürokrasi, belli derece ve hiyerarşi içerisindeki memurlardan oluşur. Bu memurlar topluluğu, kurallarla çalışan ve otoriteyi temsil eden kimselerden meydana gelir. Bkz. Max Weber, Bürokrasi ve Otorite, Çev. H. Bahadır Akın, 8. Bs., Liberte Yayınları, Ankara 2017, s. 29.

12 Yılmaz, s. 86, 89; Soyak, s. 168; Ayrıca bkz. Friedrich A. Hayek, “Liberalizm”, Çev. Ünsal Çetin, Hayek’in Liberalizm Anlayışı (İçinde), 1. Bs., Kesit Yayınları, İstanbul 2012, s. 49.

13 Benzer yönde bkz. Yılmaz, s. 95. Planlamacılığın ilk aşamalarından görülebilecek olan sosyal devlet ve hukukun üstünlüğü ilişkisi için ayrıca bkz. Ernst Rudolf Huber, "Modern Endüstri Toplumunda Hukuk Devleti ve Sosyal Devlet", Çev. Tuğrul Ansay, Ankara Üniversitesi Hukuk Fakültesi Dergisi, C. 27, S. 3, Y. 1970, s. 47-51.

14 Bencil - egoist-, TDK’da; “Yalnız kendini düşünen, kendi çıkarlarını herkesinkinden üstün tutan” şeklinde tanımlanmaktadır. Bkz. https://sozluk.gov.tr (14.05.2020). TDK’nın sözlüğünde de belirtildiği üzere bencil kimse kendi menfaatlerini, kendi tercihlerini yaşamın mutlak ilkesi yaparken, toplumun ya da başkalarının çıkarlarını görmezden gelir. Konu hakkında ayrıca bkz. Gürsen Topses, "Elseverlik (Alturizm) ve Benseverlik (Egoizm) Ölçeğiyle İlgili Geçerlik ve Güvenirlik Çalışması”, International Journal of New Trends in Arts, Sports \& Science Education, C. 1, S. 2, Y. 2012, s. 61-63.

15 Hayek, Kölelik Yolu, s. 36, 91-92. Hayek, bu konuda piyasa düzeni tehdit edenin bireysel bencillik (veya özel şirketlerin bencil davranışları) değil, örgütlü grupların bencilce davranışları olduğunu söyler. Zira yazara göre örgütlü gruplar gücünü siyasi iktidarın sağladığı yardımlar sayesinde edinir. Hayek, örgütlenme hürriyetinin bu bağlamda belli bazı sınırlarının olmadığının düşünülmemesi gerektiğini de ayrıca vurgular. Bu konuda ayrıca bkz. Friedrich A. Hayek, Hukuk, Yasama ve Özgürlük - Özgür Bir Toplumun Siyasi Düzeni, Çev. Mehmet Öz, Türkiye İş Bakası Kültür Yayınları, İstanbul 1997, s. 133-134.

16 Friedrich v. Hayek, Individualism and Economic Order, 3. Bs., The University of Chicago Press, Chicago 1958, s. 23.

17 Benzer yönde bkz. Yuriy Gorodnichenko/Gerard Roland, "Understanding the Individualism-Collectivism Cleavage and Its Effect: Lessons from Culturel Psycgology”, IEA Conference Volume Series (İçinde), C. 150, Y. 2012, s. 2, https://eml. berkeley.edu/ groland/pubs/IEA\%20papervf.pdf (E. 21.09.2020); Mustafa Erdoğan, Anayasal Demokrasi, 13. bs., Siyasal Kitabevi, Ankara 2017, s. 160; Erdoğan Keskin, Anayasa Hukukunda Anayasacılık Düşüncesi, Adalet Yayınevi, Ankara 2020, s. 59. Diğer taraftan hukukun üstünlüğü mülkiyet hakkını da hürriyetin dayanağı ve başarının temel kaynağı olarak görür. Ayrica bkz. Huber, s. 47. 
Hayek'e göre bireycilik kavramı, bireye sırf insan olması sebebiyle saygı duymak, tüm tercih ve kanaatlerinin kişinin kendi meselesi olduğunu kabul etmektir. Bu bağlamda bireycilik, kişinin otonom bir varlık olduğunu bilmek ve onun bu özerk alanına saygı duymak demektir. Kişinin kendi iyisini seçmesi ve dilediği hayat tarzına sahip olması ise ilk olarak 17 ve 18. yüzyıllar arasında liberal fikirlerin ve özellikle rekabete dayalı ticari hayatın gelişmesiyle mümkün hale gelmiştir ${ }^{18}$. Düşünüre göre ticaretin serbestliğiyle başlayan bu gelişim ve bireyselleşme bilimsel gelişmelere de büyük bir katkı sağlamıştır ${ }^{19}$.

Öyleyse liberal devlet ve hürriyet anlayışının temeli olan bireycilik, merkezi kontrol mekanizmalarıyla uyumlu değildir. Bireyciliğin gelişmesinden önce; sosyal, siyasi ve ekonomik hayatta da kuşkusuz birey yerine toplum gözetilmiştir. Hayek'e göre, birey ve onun tercihlerinin önemsenmediği yerde, çoğunluğun inançları, ahlakı ve dolayısıyla taassubu vardır. Bu durum bilimsel ve teknolojik gelişmelere engel teşkil eder. Zira tarihi tecrübeler göstermiştir ki, bireyin görüşlerinin önemsenmemesi ve hatta kimi zaman bu görüşler nedeniyle kişilerin tehlike altında kalması gelişimi engeller ${ }^{20}$. Ancak sanayinin gelişimi ve bilginin serbestçe kullanımı yeni girişimlere, isteğe bağlı tecrübelerin artmasına ve gelişmesine yol açmışıิ ${ }^{21}$.

Liberal düşüncenin veya konu itibariyle bireyciliğin neden toplumsal dogmalar ve menfaatlerin takip edilmesine oranla gelişmeyi daha çok tetiklediği sorusu, elbette akla gelebilir. Nitekim herkesin ortak çıkar gözetmesi, aynı hedefe tüm toplumun gayretini sevk etmesi ve adeta hedef birliği içerisinde oluşan kardeşlik, herkesin kendi “iyisini” takip etmesinden daha makul değil midir? Hayek'in bu tür sorular karşısında verebileceği kuşkusuz birçok cevap vardır. Örneğin bu cevaplardan birisi, liberalizmin değiştirilemez bir dogmaya, sabit prensiplere dayalı olmamasıdır. Liberal düşünce ve bireycilikte aslolan devlet ve başka bir merkezi gücün birey ve onun tercihleri üzerinde zor kullanımının olmaması ve kendiliğinden oluşan toplumsal düzenin korunmasıdır ${ }^{22}$. Dolayısıyla, bireylerin tercihlerinin ve hedeflerinin dışlanmaması temelinde birçok liberal tatbik şeklinden söz edilebilir ${ }^{23}$. Diğer bir ifadeyle, liberal düşünce dogmalardan uzaktır. Hayek’in ifadesiyle düşünsel olarak en kapsamlı anlamıyla farklı şekillerde karşımıza çıkabilecek bir bireycilik ve hürriyet birlikteliğidir ${ }^{24}$.

18 Hayek, Kölelik Yolu, s. 36. Bu yüzyıllarda liberal düşünce karakter kazanmıştır. Söz konusu gelişmelerle, bireysel hürriyetlerin hukukun üstünlüğü ile güvence altına alındığından söz edilebilir. Bkz. Hayek, Liberalizm, s. 34.

19 Hayek, Kölelik Yolu, s. 37. Hayek, birey hürriyetlerinin 17. yüzyıl İngiltere’sinden daha geriye götürülemeyeceğini belirtir. Ona göre hürriyet belli bir amacın ve planın sonucu olmaktan çok iktidar mücadelesinin yan ürünüdür. Buna karşılık hürriyet sağladığı faydalar nedeniyle kabule mazhar olmuştur. Bkz. Friedrich v. Hayek, Özgürlüğün Anayasasl, Çev. Yusuf Ziya Çelikkaya, Bigbang Yayınları, Ankara 2013, s. 253-254; Yayla, s. 50; Friedrich A. Hayek, The Constitution of Liberty, The University of Chicago Press, 1978, s. 162-163.

20 Hayek, Kölelik Yolu, s. 36-39.

21 Hayek, Kölelik Yolu, s. 36.

22 Hayek, Kölelik Yolu, s. 39-40; Atilla Yayla, "Hayek'in Fikir Dünyasında Liberalizm”, Hayek’in Liberalizm Anlayışı (İçinde), 1. Bs., Kesit Yayınları, İstanbul 2012, s. 14-15.

23 Hayek, Kölelik Yolu, s. 40. Liberal toplumda birden fazla değer çeşidi bir arada yaşar. Bu değerlerin uyumlu olması gerekmediği gibi çatışması da normaldir. Bkz. Yayla, Hayek'in Fikir Dünyasında Liberalizm, s. 14. 
Bu düşüncenin hakimiyet kurmasına kadar gelen sürede herkesin uyduğu ve takip etmesi gereken prensipler, bireylerin öğrenme arzusunu engellemiştir. Yeni bir fikir ortaya atma düşüncesi, ortak inançlar karşısında her zaman zayıf kalmıştır. Ne var ki, insanın meraklı ve muhalif tabiatı, toplumsal dogmaların tartışılabileceğinin anlaşılması ve bireyciliğin gelişmesiyle birlikte, bilimsel atılımlar gerçekleşmiştir ${ }^{25}$. Hayek’in görüşlerini bu bağlamda şöyle özetleyebiliriz; insanın önünde bir set gibi duran tartışmaya kapalı dogmalar karşısında, insana yeni düşünce dünyasının kapılarını açan ve istediği tecrübeyi yaşayanları, gerektiğinde ekonomik veya sosyal bazı riskleri göze alanları koruyan, esası özerklik olan bireycilik, elbette gelişimin anahtarıdır.

Tüm bu gelişmeler karşısında düşünür yaşadığı dönem itibariyle dünyada ve İngiltere'de planlamacılığın ve totalitarizmin yükselişe geçtiğine tanıklık etmiştir. Bu nedenle de kolektivist amaçlar karşısında bireyciliğin önemli bir savunucusu olmuştur. Hayek'in tanıklık ettiği gelişmeler hür toplumda kendiliğinden doğan düzenin terkedilmeye başlanmasıdır. Rekabete dayalı pazar ekonomisinin tasarlanmamış mekanizması yerine, bütün yönleri düşünülmüş ve tasarlanmış amaçlara, kolektif ve şuurlu bir şekilde toplumun ve ekonominin sevk ve idaresi savunulmaya başlamıştır ${ }^{26}$. Devletin birey yerine, toplumun refahı ve gelişimi adına ekonomiyi merkezi olarak planlaması, diğer bir ifadeyle bireyin amaçları yerine, toplumun tasarlanan amaçlara sevk edilmesi düşüncesi yükselişe geçmiştir.

Bu durum, kolektivizm olarak adlandırılabilir. Yani insanların topluca belli bir amaç için hareket etmesi ve bireysel amaçlar yerine ortak hedefler uğruna birlikte çalışması kolektivizm olarak ifade edilmektedir ${ }^{27}$. Kolektivizm, birey çıkarları değil, cemaat çıkarlarını gözetir. Bu yaklaşımda teklik, bireysellik yoktur; ancak cemaat, diğer bir ifadeyle grup vardır. Bireyler, ancak bu grupla tanımlanıp, anlam kazanabilir. Dolayısıyla insanlar, ortak bazı bağlarla birbirine bağlanmış sosyal varlıklardır ${ }^{28}$. Hayek bu kapsamda ayrıca kolektivizmden, ekonominin merkezileștirilmesinin, başka deyişle planlamacılığın anlaşılabileceğini dile getirir. Kendisi de bu kavramı kullanırken kimi zaman planlamacılığı kasteder. Ancak planlamacılığın daha iyi anlaşılabilmesi için kavramları ayrıca açıkladığını söylemek kanaatimizce uygun bir tespittir ${ }^{29}$.

Neticede böyle bir toplumda, bireyin varlığı eritilmiştir. Devletin müşterek faaliyetlerinin genişlemesiyle birlikte bireye doğrudan müdahale edilmese bile hürriyet alanı daraltılır ${ }^{30}$; devletin faaliyet alanı genişledikçe, ekonomi devletin kontrolüne girer. Hayek'in belirttiği gibi böyle bir toplumda, ki düşünür Nazi Almanya’sını örnek vermektedir, bireyin gerçekleştirebileceği bir

25 Hayek, Kölelik Yolu, s. 37-38.

26 Hayek, Kölelik Yolu, s. 43. Hayek'in kendiliğinden düzeni somut bir iradenin sonucu değildir. Kendiliğinden düzen, somut amacı olmayan, anonim amaçları ve planlanmamış bir seyri olan, yani spontane gelişen bir düzeni ifade eder. Bkz. Yayla, Hayek'in Fikir Dünyasında Liberalizm, s. 14.

27 Ayrıca bkz. Heywood, Siyaset Teorisine Giriş, s. 51.

28 Ayrıca bkz. Heywood, Siyaset Teorisine Giriş, s. 51.

29 Bkz. Hayek, Kölelik Yolu, s. 60.

30 Hayek’e göre tehlike devletin ticari faaliyette bulunması değildir. Onun karşı olduğu ve asıl tehlikeli olarak değerlendirdiği devletin kontrolünün dar sınırlar içerisinde kalmayıp ekonomik faaliyetlerini büyük bir kısmını kontrol altına almasıdır. Bkz. Hayek, Özgürlüğün Anayasası, s. 338-339; Hayek, The Constitution of Liberty, s. 227-228. 
münferit amaç kalmaz. Bu durumda toplumun, dolayısıyla devletin amaçları tüm bireylerin amaçlarının üzerine çıkar ${ }^{31}$. Tasarlanan düzeni sağlamak adına belirlenen bir amacı takip etmek için hukuku bir tür araç gören planlamacılık savunucularına karşılık Hayek, hukukun belli bir amaç için yapılmadığını veya yapılamayacağını belirtir. Düşünüre göre hukuk, bireylerin önceden belirlenen amaçları takip etmesini sağlamak için değil, tersine kişilerin kendi amaçlarını gerçekleştirebilmesini sağladığı için gelişmiştir ${ }^{32}$.

Bireyin değil de toplumun menfaatlerinin ve amaçlarının en üstün konumda görülmesi, genelde sosyal adaleti sağlama gibi hemen herkesin arzu edebileceği ütopik bir rüyanın eseridir ${ }^{33}$. Düşünüre göre, hemen herkesin bu amaç için ekonominin merkezileşmesini ve kolektif hedefleri kabullenmesi mümkün olsa bile, bu amaç için tüm olaylara yönelik önceden kuralların belirlenmesinin ve karar alınmasının belirsizlik oluşturduğunu belirtir. Yani insanlar planlamacılık üzerinde bir anlaşmaya varmış olsa da bu durum belirlenen hususi hedefler üzerinde anlaşmanın sağlandığını ya da anlaşmanın kolaylığını göstermez ${ }^{34}$. Hayek bunu, herkesin ortak bir yolculuğa çıkma konusunda anlaşmasına rağmen, yolculuğun nereye yapılacağının belirlenmemiş olmasına benzetir. Bu durumda kimileri bilmedikleri veya gitmek istemedikleri, ancak aralarından birilerinin tercih ettiği yere yolculuk etmek zorunda kalır ${ }^{35}$. Böyle bir toplumda, kolektivist toplumda, devlet tüm imkanlarıyla ve baskı tekeliyle toplumu tek bir hedefe yönlendirir. Bireyin arzu ve tercihlerinin önemsenmediği, kamu yararı veya kamu düzeni gibi belirsizlik içeren, muğlak kavramların sıklıkla kullanıldığı bu devletler, Hayek'e göre, faşizm ve sosyalizm gibi ideolojilerin benimsendiği totaliter devletlerdir ${ }^{36}$.

Böyle bir toplumda hürriyetten söz edilemez. Zira kamu yararı ve öncelik bahşedilen toplumsal ihtiyaçlar gibi kavramların ne ifade ettiği belirsizdir. Planlamaya göre belirlenen ihtiyaçların ne olduğu ve öncelik sıraları kişiden kişiye değişir. Hayek, refahın/menfaatlerin sağlanabilmesi için önce bu menfaatlerin belirli bir sıralamada tespit edilmiş olması gerektiğini vurgular. Ancak bu menfaatlerin kimler için doğru olduğunu ve herkesin müşterek menfaatinin ne olduğunu tespit etmeye yarayan bir ölçüt olmadığı gibi planlamayı yaparak, belirlenen kolektif hedeflerin herkesçe nasıl kabul edileceği de, Hayek'e göre belirsizdir ${ }^{37}$.

31 Hayek, Kölelik Yolu, s. 93.

32 Friedrich A. Hayek, Kanun, Yasama Faaliyeti ve Özgürlük-Kurallar ve Düzen, Çev. Atilla Yayla, Türkiye İș Bankası Kültür Yayınları, İstanbul 1994, s. 169; Eamonn Butler, Hayek, Çev. Yusuf Ziya Çelikkaya, 2. Bs., Liberte Yayınları, Ankara 2001, s. 171. Ancak emirlere dayalı bir yönetimin ise bireylerin değil, o emirleri verenlerin kendi amaçlarını gerçekleştirmeye hizmet ettiğini belirtir. Bkz. Hayek, Özgürlüğün Anayasası, s. 236.

33 Hayek, Kölelik Yolu, s. 93-94. Eşitlik ve adalet söylemi etrafında Avrupa Kıtası’nda halk ayaklanması diyebileceğimiz ayaklanmalar 1848 Devrimleri olarak adlandırılır. Bu ayaklanmalar Avrupa genelinde devletin eşitliği sağlaması, eşitliği ortadan kaldıran feodal ya da soya bağlı diğer ayrıcalıkların kaldırılmasını, herkesin asgari yaşam standardına ulaştırılması gibi çeşitli talepleri gündeme getirmiştir. Ancak bu talepler, planlamacılığa yol açabilecek boyutlara ulaşamamıştır. Ayrıca bkz. Roger Price, 1848 Devrimleri, Çev. Nail Kantemir, Babil Yayınları, İstanbul 2000, s. 23-51.

34 Hayek, Kölelik Yolu, s. 93-94; Bkz. Butler, Hayek, s. 172.

35 Hayek, Kölelik Yolu, s. 93-94. Hayek, planlamacıllğ ${ }_{1}$ herkes kendi gibi olsun isteyenlerin daha çok tercih ettiğini belirtir. Bkz. Hayek, Kölelik Yolu, s. 85-86.

36 Hayek, Kölelik Yolu, s. 88.

37 Hayek, Kölelik Yolu, s. 89. 
Açıklanan kolektif şartlarda bireyler tercihte bulunurken, başkalarının tercih sırasına uymaya mecbur bırakılmaktadır. Bunun yerine düşünüre göre, bireyler serbest bırakılmalı; herkes münferiden kendi amacını gerçekleştirmeye çalışabilmeli ve başkasının diktatörlüğüne, kontrolüne bırakılmamalıdır ${ }^{38}$. Bireylerin kendi iyilerini ve amaçlarını takip etmesi bireyin tamamen bireysel menfaati takip eden, egoist varlıklar olduğu anlamına gelmez. Toplumu oluşturanların elbette üzerinde anlaşmaya vardığı konular, bu bağlamda da topluca aldığı ya da alabileceği kararlar yok değildir ${ }^{39}$. Aynı toplumun fertlerinin ortak noktaları olabilir. Ortak hedefler hususunda bireyler birlikte hareket etmeyi tercih edebilirler. Bu düşünceleri desteklemek adına Hayek, bireylerin ortak noktada birleşmesinin en büyük görünümü olarak devleti gösterir. Her ne kadar devletin faaliyet alanında bireysel tercihler bazı durumlarda farklılık arz etse de belli bir noktada herkesin bazı devlet faaliyetlerinde uzlaşacağı konusunda da şüphe yoktur ${ }^{40}$. Ancak hürriyetlerin müdafaası adına karşı çıkılan husus, bireyin toplum ve toplumsal amaçlar pahasına görmezden gelinmesidir. Sonuç olarak, kolektivizm/ planlamacılık tüm devlet ve toplum faaliyetlerinin belli amaçlara yönlendirilmesine neden olur ${ }^{41}$. Hayek'e göre kolektivizm bireye, planlanan hedefe ulaşmak için bir ahlaki kodu dayatmaktır; bu da serbestliğin sonu demektir ${ }^{42}$.

\section{HUKUKUN ÜSTÜNLÜĞÜ ve DEVLET KONTROLLÜ YAŞAM}

\section{A. Genel Olarak Hukukun Üstünlüğü}

Hukukun üstünlüğü genel olarak bireysel hak ve hürriyetlerle, bireylerin özerk alanlarının korunması adına siyasi iktidarın önceden ilan edilen, genel, açık-anlaşılır ve benzer diğer nitelikleri haiz hukuk kurallarına uygun şekilde hareket etmesi olarak tanımlanabilir. Ayrıca hukukun üstünlügünün sağlanmasına yönelik farklı alt ilkeler gerekli görülmektedir ${ }^{43}$. Yani devlet organlarının hukuka itaat etmesinin sağlanmasının, iktidarın keyfi davranışlarının önlenmesinin, hukuk kurallarının hürriyetleri korumak amacina hizmet etmesinin ve bireylerin toplumun bir ferdi olarak huzur içerisinde yaşamasının sağlanabilmesi için bazı araçların ve ilkelerin temin edilmesi gerekir. Örneğin bu bağlamda Fuller, hukukiliğin mükemmelliğinin sağlanabilmesi için "kanunun ilan edilmesi, genel nitelikte olması, açık ve anlaşılır olması, çelişkili olmaması, zaman içerisinde belirli bir süreklilik arz etmesi, toplum içinde gerçekleştirilmesi imkânsız olanı istememesi, geçmişe etki etmemesi ve hukuk kurallarıyla onların uygulanması arasında uyum olması gibi sekiz adet ilke gerekli görür ${ }^{44}$. Neticede

38 Hayek, Kölelik Yolu, s. 91-92.

39 Hayek, Kölelik Yolu, s. 91-92.

40 Hayek, Kölelik Yolu, s. 92; Hayek, The Road to Serfdom, s. 36. Piyasa içerisinde arz edilemeyen, bu nedenle devlet tarafından sunulması gereken birçok mal ve hizmet vardır. Bunlar halka sunulduğu zaman pek çok kişiye fayda sağlayan ve çoğu kişi tarafından talep edilen hizmetlerdir. Bkz. Hayek, Liberalizm, s. 70. Devletin bu hizmetleri sunması kaçınılmazdır. Zira devletin hiçbir faaliyetinin ya da hürriyetler üzerinde zorlayıcı etkisinin olmadığı bir toplum hayal edilemez. Bkz. Atilla Yayla, Özgürlük Yolu, Profil Yayıncılı, İstanbul 2014, s. 43-44.

41 Hayek, Kölelik Yolu, s. 87. Liberalizme göre ise devletin eylem ve işlemlerini keyfi yapan, bu eylem ve işlemlerin bireylerin devletçe belirlenen amaçlara sevk edilmeleridir. Bkz. Hayek, Liberalizm, s. 56.

42 Hayek, Kölelik Yolu, s. 90 - 91.

43 Bkz. Martin Loughlin, Foundations of Public Law, 1. Bs., Oxford University Press, Chennai 2010, s. 333.

44 Bkz. Lon L. Fuller, Hukukun Ahlakı, Çev. Engin Arıkan, 1. bs., Tekin Yayınevi, İstanbul 2016, s. 53-54, 56-59. Görüldüğü 
hukukun üstünlügü gerek kuralların bazı niteliklere sahip olmasını gerekse devlet organlarının bazı kural ve ilkelere göre hareket etmesini ifade etmektedir ${ }^{45}$.

\section{B. Hayek'te Hukukun Üstünlügüü}

\section{Genel Olarak}

Hayek’in hukukun üstünlüğü düşüncesine ilişkin yaklaşımı, "hukuk" anlayışılla paralellik arz eder ${ }^{46}$. Dolayısıyla Hayek’te hukukun üstünlügü kendiliğinden düzen ve serbest piyasa ile yakından ilişki içerisindedir. Ancak Hayek, hukukun üstünlügüne ilişkin kapsayıcı bir kavramsal analiz yapmış değildir. Bununla birlikte her ne kadar bir sonraki başlıkta kapsamlı olarak ele alınacak olsa da düşünür, hukukun üstünlüğünü genel olarak, siyasi iktidarın eylemlerini önceden ilan edilmiş kurallara uygun şekilde gerçekleştirmesi olarak ele alır ${ }^{47}$.

Hayek'in hukukun üstünlüğü düşüncesi temelde iktidarı, bireyin özerk alanı ve kendiliğinden düzenin korunması karşısında kontrol altında tutmayı hedefler. O, bu amaca yönelik olarak ilkenin sağlanabilmesi adına kuralları genellik ve belirlilik bakımından bir nevi teste tabi tutar ${ }^{48}$. Hayek'in kuralların genelliği ve belirliliğine ilişkin hassasiyeti, onun ilkeyi yalnızca biçimsel olarak ele aldığının düşünülmesine yol açmıştır. Örneğin Aktaş, Hayek’in anlayışının kuralların içeriğiyle değil,

üzere altıncı ilke hariç diğerleri şekle ilişkin şartlardır. Ancak Fuller’in bu ilkeleri gerekli görmesindeki maksat, hukukun iç ahlakiliğinin bu ilkelerle sağlanacağına inanmış olmasıdır. Fuller, kanunların bu ilkelerden bir tanesine bile uygun olmaması halinde kötü bir hukuk sisteminin ortaya çıkmasından öte, hukuk sisteminin varlığından bile söz edilemeyeceğini söyler. Dolayısıyla bir hukuk sisteminin varlığından söz edilebilmesi için hukuk kurallarının sekiz adet ilkeye uygun olması gerekir. Bkz. Fuller, s. 54; Vahdet İşsevenler, "Hukukun Erdemi ve Fuller'in Ahlakları", IÜHFM, C. LXXIV, S. 2, Y. 2016, s. 578. Bu gereklilikler birçok düşünür tarafından farklı ilkelerin benimsenmesi şeklinde anlam bulmuştur. Butler de Fuller’e benzer şekilde, hukukun üstünlüğünü bazı kalıcı ilkelere dayandırmaktadır. Çünkü ona göre, hukukun üstünlüğü tabii adaletin teminatıdır. Butler, eşit ve adil yargılanma hakkı, bağımsız hâkim ve savcıların varlığı, tarafsız mahkemeler, duruşmasız uzun süre tutuklu kalmama, hiç kimsenin suçluluğu ispat edilmeden suçlu sayılamayacağı ve kanunların açık ve sürekli olması gibi bazı alt ilkeleri gerekli görür. Bkz. Eamonn Butler, Özgür Toplumun Temelleri (Çev. Hakan Şahin), 1. bs., Liberte Yayınları, Ankara 2016, s. 137. Yine, Peter Rijpkema da benzer şekilde her hukuk sisteminin veya kurallarının varlığını, hukukun üstünlüğünden ayrı değerlendirir. Ona göre, hukukun üstünlüğünün sağlanabilmesi için bazı asgari şartların sağlanmış olması gerekir. Rijpkema’ya göre bu şartlar, hukuk kurallarının açık ve anlaşılır olması, makul bir süre istikrarlı, genel olması, toplum için imkânsız olanı istememesi ve kanunların birbirleriyle çelişmemesidir. Bkz. Peter Rijpkema, "The Rule Of Law Beyond Thick and Thin", Law and Philosophy, S. 32, Y. 2013, s. 799-802.

45 Hayek ise hukukun üstünlüğü ilkesinin teoriden uygulamaya geçmesinin ancak 18. yüzyılda mümkün olduğunu belirtir. Ona göre, 1701'de Act of Settlement ile birlikte hakimlere bağımsızlı̆ın sağlanması, yasamanın keyfi hareket etmesini önlemeye ve kuvvetler ayrılığının yeniden önem kazanmasını sağlayan 1706 son Bill of Attainder kararının geçtiği dönem, hukukun üstünlügüne dair ilkelerin gelişmesi dönemidir. Bkz. Hayek, Özgürlüğün Anayasası, s. 265-266. Bill of Attainder; bir kişinin yargılaması yapılmadan kanunla suçlu ve/veya hain olarak ilan edilmesidir. Bkz. https://www. dictionary.com/browse/bill-of-attainder, (24.05.2020).

46 Sururi Aktaş, Hayek’in Hukuk ve Adalet Teorisi, 2. Bs., Liberte Yayınları, Ankara 2018, s. 165.

47 Aktaş, Hayek'in Hukuk ve Adalet Teorisi, s. 165; Bkz. Hayek, The Road to Serfdom, s. 78.

48 Benzer yönde bkz. Aktaş, Hayek'in Hukuk ve Adalet Teorisi, s. 166. Doktrinde birçok yazar kuralların genel nitelikte olması gereği üzerinde durur. Örneğin Fuller, insan davranışlarını yönlendirecek bir sistemde il olarak kuralların olmasını ve bu kuralların da genel nitelikte olmasını gerekli görür. Fuller, s. 62; Sururi Aktaş, Prosedürel Doğal HukukLon L. Fuller'in Hukuk Kavramı, 1. bs., On İki Levha Yayıncllı, İstanbul 2010, s. 17. 
şekli özellikleriyle ilgili olduğunu belirtir ${ }^{49}$. Ancak Hayek, bireyi hür kılan kanunun yalnızca şekli anlamda kanun olmadığını dile getirir. Ona göre, burada bahsi geçen kanun maddi anlamdan kopuk olmayan kanundur. Zira özel amaçları gerçekleştirmeye yarayan kanunların sırf yasama organından çıkmış olması bizi hür kılmaya yetmez. Bu tür kurallar yalnızca baskı araçları olarak görülebilir ${ }^{50}$. Dolayısıyla Hayek bir hürriyetperver olarak, kanunların yalnızca bazı niteliklere sahip olmasını ve kanunların yasama organınca yapılmasını yeterli görmüş olamaz ${ }^{51}$. Bununla birlikte şu tartışmasız bir gerçektir ki Hayek düşüncesinde kuralların, sosyal ve ekonomik eşitliği sağlaması gibi bir amacı da yoktur ${ }^{52}$.

\section{Hayek'te Hukukun Üstünlüğ̈̈nün Gerekleri ve Hürriyet}

Hayek hukukun üstünlügüne dair görüşlerini bireysel hürriyetler ve rekabete dayalı ekonomi üzerinden hareketle ele alır. Hayek'e göre hukukun üstünlüğü hür bir toplum ile hür olmayan toplum arasındaki farktır. Diğer bir ifadeyle hukukun üstünlügü, hür bir toplumla hür olmayan toplumu birbirinden ayırır ${ }^{53}$.

Hayek’e göre hukukun üstünlügüu, başta siyasi iktidarın bütün faaliyetlerinin belirli ve önceden ilan edilen kurallara bağlı olmasıdır. Dolayısıyla hukukun üstünlüğü, bireylere iktidarın eylem ve işlemlerinin gelecekte nasıl olacağı yönünde bir tür öngörülebilirlik sağlar ${ }^{54}$. Zira belirlenmiş hukuk kuralları belli hal ve şartlarda hükümetin eylemlerinin ne olacağını önceden tespit eder. Düşünüre göre bu kurallar soyut, kişilik dışı, yani genel olmalıdır. Somut olarak bilinemeyecek, herkesin her an karşılaşabileceği durumlara uygulanmaya yönelik olmalıdır. Kuralların bu nitelikte olması, bireylerin geleceği öngörerek geleceklerine ilişkin amaçlarını ve eylemlerini belirlemelerini ve bunları takip etmelerini sağlar ${ }^{55}$. Bu kurallar, aynı zamanda genel nitelikte olmaları bağlamında, onların hangi

49 Aktaş, Hayek'in Hukuk ve Adalet Teorisi, s. 166. Hayek kanunların bireylere herhangi bir amaç dayatmaması gerektiğini belirtir. Aktaş da diğer bir eserinde, Hayek'in hukuku üstünlüğü anlayışının kanunların içeriğiyle tamamen ilgisiz olmadığını ifade eder. Bkz. Sururi Aktaş, “Hukuk Devleti İdealine Felsefi Bir Bakış”, YBHD, Sayı 2020/1, s. 18-19.

50 Hayek, Özgürlüğün Anayasası, s. 244. Hayek, kanunların varlığı gerekli olsa da bu yeterli değildir. Kanunların ayrıca bazı nitelikleri haiz olması Hayek’in hukukun üstünlüğü düşüncesinde bir gerekliliktir. Bkz. Aktaş, Hukuk Devleti İdealine Felsefi Bir Bakış, s. 19.

51 Ayrıca bkz. Hayek, Özgürlügün Anayasası, s. 242-245.

52 Aktaş, Hayek'in Hukuk ve Adalet Teorisi, s. 166. Konuya ilişkin değerlendirme ve açıklamalar için ayrıca bkz. Aktaş, Hukuk Devleti İdealine Felsefi Bir Bakış, s. 19.

53 Hayek, Kölelik Yolu, s. 107; Hayek, The Road to Serfdom, s. 75-76; Friedrich A. Hayek, "Liberal Bir Sosyal Düzenin İlkeleri”, Hayek'in Liberalizm Anlayışı (İçinde), 1. Bs., Kesit Yayınları, İstanbul 2012, s. 85; Aktaş, Hukuk Devleti İdealine Felsefi Bir Bakış, s. 17.

54 Hayek, Kölelik Yolu, s. 107; Hayek, Özgürlüğün Anayasası, s. 336; Hayek, The Road to Serfdom, s. 75-76. Kuralların belirliliğini, bireylerin davranışlarını yönlendiren kuralların herkesin erişebileceği şekilde ilan edilmesi ve en azından toplumun makul bir kesimi tarafından anlaşılabilecek nitelikte olması olarak tanımlayabiliriz. Aksi halde bireylerin erişemediği veya anlayamadığı kurallara muhatap tutulmaları hukukun değil, kişinin ve baskının yönetimine yol açar. Konuya ilişkin ayrıca bkz. Keskin, s. 221-225.

55 Hayek, Kölelik Yolu, s. 111; Hayek, The Road to Serfdom, s. 75-76; Konu hakkında ayrıca bkz. Hayek, Liberalizm, s. 55; Hayek, Liberal Bir Sosyal Düzenin İlkeleri, s. 92; Yayla, Özgürlük Yolu, s. 42-64; Aktaş, Hukuk Devleti İdealine Felsefi Bir Bakış, s. 17. Öngörülebilirlik, bireylerin kendilerine uygulanacak kuralları bilerek geleceğe yönelik hazırlık yapabilmesini, tercih ve eylemlerini yönlendirebilmelerini sağlar. Bkz. Erdoğan, Anayasal Demokrasi, s. 118; İsmail 
özel amaçlara hizmet edeceği, kimin menfaatine veya kimin zararına yol açacağı bilinemediğinden, tüm insanların "muhtemel iyiliği”ne hizmet eder. Birilerinin iyilerini ve amaçlarını tercih etme, yani koruma amacından oldukça uzaktır ${ }^{56}$.

Hayek'in kuralların belirliliğinden ve kişilik dışı olmasından beklediği fayda bireylerin serbestçe geleceklerini tayin edebilmeleridir. Bu serbestlik kişileri hür kılar; gelecekte kişilerin hangi iyileri ve eylemleri takip edebileceği konusunda bir güvence sağlar ${ }^{57}$. Ancak bu serbestlik sınırsız bir hareket alanını ifade etmez. Düşünüre göre, rekabete dayalı, liberal ekonomi ve hürriyet anlayışındaki birliktelik, esasen baskıcı müdahaleleri dışlasa da devletin müdahalelerini tamamen dışlamaz. Dolayısıyla liberal düşünce devletin bazı hallerdeki faaliyetleriyle uyumludur ${ }^{58}$. Diğer bir ifadeyle kurallar bazı durumlarda bireylerin kullanabilecekleri araçları sınırlandırabilirler ${ }^{59}$. Buna göre herkese eşit şekilde uygulanan genel ve soyut kurallar hürriyetlerin sınırlandırılmasına yol açabilir. Ancak Hayek'e göre, bu niteliklere sahip kuralların hürriyet rejimini ciddi ölçüde sınırlandırması düşük bir olasılık olmasının yanında bu kurallar yalnızca yönetilenler için sorumluluk doğurmaz ${ }^{60}$. Bu kurallar aynı zamanda yönetenler üzerinde de sorumluluk ve bağlayıcılık doğurur; herhangi bir kimse ya da grubun da kayırılmasını ve imtiyazlı kılınmasını tamamen dışlar ${ }^{61}$.

Görüldüğü üzere Hayek devletin bazı durumlarda müdahil olmasını gerekli görür ${ }^{62}$. Bu konuda bazı örnekler verir. Örneğin, zehirli madde kullanımın yasaklanması, hastane yapımının öngörülmesi, çalışma saatlerinin düzenlenmesi gibi kamu sağlığı ve düzenine ilişkin temel meseleleri devlet düzenler. Ona göre piyasadaki rekabet de kamu hizmeti mantığıla uyumsuz değildir. Önemli olan devlet faaliyetlerinin rekabeti işlemez kılmaması ve anlamsız hale getirmemesidir ${ }^{63}$.

Köküsarı, Anayasa Hukukunda Hukukî Güvenlik İlkesi, Adalet Yayınevi, Ankara 2015, s. 138; Keskin, s. 225.

Hayek, Kölelik Yolu, s. 111; Hayek, The Road to Serfdom, s. 77-78. Ancak Hayek genel kuralların değil, genel olmayan emirlerin onları çıkaran kişi ya da grupların kendi amaçlarına hizmet ettiğini belirtir. Bkz. Hayek, Özgürlüğün Anayasası, s. 236. Kuralların genelliği, kuralların özel durumlara ve ihtiyaçlara göre tasarlanmasının önündeki bir engeldir. Fuller, s. 62; Aynı yönde bkz. Turan Güneş, Türk Pozitif Hukukunda Yürütme Organının Düzenleyici İşlemleri, 1. bs., Sevinç Matbaas1, Ankara 1965, s. 14-15; Keskin, s. 219.

57 Hayek, Kölelik Yolu, s. 111; Hayek, The Road to Serfdom, s. 75-76; Yayla, Hayek'in Fikir Dünyasında Liberalizm, s. 12. Bu kapsamda Boudreaux, otoyol kurallarını örnek verir. Örneğin trafik 1şıkları sürücülerin nereye gideceğine karar verme amacına sahip değildir. Ancak trafik ışıkları sürücülerin yolculuğunu güven içinde tamamlamalarını hedefler. Dolayısıyla hukukun üstünlüğü bağlamında kanunlar ancak bu şekilde bireylerin özerk alanını muhafaza etmeyi hedeflemelidir. Bkz. Donald J. Boudreaux, Yeni Başlayanlar İçin Hayek, Çev. İlkay Yılmaz, Liber Plus Yayınları, İstanbul 2017, s. 47-51.

58 Hayek, Kölelik Yolu, s. 63; Yayla, Özgürlük Yolu, s. 44. Herkes için eşit şekilde hürriyetin korunması gerekir. Burada hürriyet sınırsız bir hareket alanı sunmaz. Liberalizmin anarşizmden farkı da burada ortaya çıkar. Bkz. Hayek, Liberalizm, s. 53 .

59 Hayek, Kölelik Yolu, s. 108; Butler, Hayek, s. 171. Bu müdahaleler, somut amaçları elde etmek için yapılmaz. Hür toplum düzeninde yapılan müdahaleler herkesin eşit şekilde hür olmasını sağlamak için yapılır. Hürriyetin anlamı da bireyin keyfi müdahalelerden korunmasından başka bir şey değildir. Bkz. Yayla, Hayek’in Fikir Dünyasında Liberalizm, s. 11-12.

60 Hayek, Özgürlüğün Anayasası, s. 242; Butler, Hayek, s. 171-172.

61 Hayek, Özgürlüğün Anayasası, s. 242; Hayek, Liberalizm, s. 64-65; Hayek, The Road to Serfdom, s. 78.

62 Hayek, Kölelik Yolu, s. 64-69; Hayek, Liberal Bir Sosyal Düzenin İlkeleri, s. 90.

63 Hayek, Kölelik Yolu, s. 64-69. Devlet, yol, köprü veya salgınla mücadele gibi sosyal ve ekonomik hayatı yakından ilgilendiren konularda faaliyet yürütebilir. Ancak devlet, kesinlikle rekabete engel olmamalı, özel teşebbüslerce yapılabilecek tüm faaliyetleri özel teşebbüslere bırakmalıdır. Bkz. Yayla, Hayek’in Fikir Dünyasında Liberalizm, s. 20. 
Zira Hayek'in hukuk ve hukukun üstünlüğü anlayışında devlet yalnızca negatif edimle yükümlü değildir. Ancak rekabetin işleyebilmesi için bir hukuk düzenine sahip olunması ile devletin yükümlülüğün yalnızca negatif olması yeterli değildir. Devletin ayrıca olumlu edimde bulunması da gerekir ${ }^{64}$. Örneğin, rekabete konu olamayacak faaliyetlerde ve mülkiyetin kullanımından kaynaklı verilen zararların tazmin ettirilmesi gibi konularda devletin dahli gerekir. Bu durumlarda rekabetten başka yollara gerek vardır. Benzer şekilde trafik ışıkları, yollar ve ağaçlar vb. hizmetlerden yararlananlardan, bu hizmetleri sürekli kullananlardan para talep edilemez. Yine fabrika dumanları gibi nedenlerden, girişimcinin sürekli tazminat ödemesi de beklenemez ${ }^{65}$. Bu tür konularda devletin olumlu edimde bulunması, bazı hizmetleri bizzat sunması ve gerekli önlemleri alması gerekir ${ }^{66}$. Hayek'e göre devletin diğer bazı pozitif edim yükümlülüklerinden bir kısmı şöyledir; etkili rekabet için şartlar oluşturmak, rekabetin işlemez olduğu hallerde yeni metotları geliştirmek, maliyeti karşılayamayacağı için kimsenin kalkışmayacağı nitelikteki hizmetleri sunmak; ancak bu durumda da yine rekabet korunmalıdır. Zira devletin olumlu edimde bulunabileceğinin kabul edilmesi bu rekabetin kaldırılabilir olduğu anlamına gelmez. ${ }^{67}$

Buna rağmen Hayek’e göre hukukun üstünlüğünün sağlanabilmesi ve dolayısıyla bireysel hürriyetlerin korunabilmesi için yürütmeye geniş takdir alanı bırakılmamalıdır. Ona göre, hukukun hakim olduğu bir rejimde hükümet - devlet - ani tedbirlerle bireylerin gayretlerini ve eylemlerini sınırlandıramaz ${ }^{68}$. Kurallar önceden belli olduğundan herkes serbest bir şekilde kendi bireysel amaçlarını ve iyilerini bu kurallara uygun olarak serbestçe takip edebilir ve hükümet bireylerin kazanımlarını ellerinden alamaz $^{69}$. Bu bakımdan iktidarın müdahale edebileceği alan oldukça sınırlı olmalıdır.

Ancak planlamacılığ savunanlar, ki Hayek yaşadığg dönem itibariyle bu kişilerin arttığını sıkça belirtir, kendiliğinden oluşan düzenin terkedilmesine neden olmuşlardır. Dönem koşullarında pazarın gayri şahsi, tasarlanmamış mekanizması yerine bütün yönleri düşünülmüş ve kararlaştırılmış; kolektif ve şuurlu bir şekilde herkesin sevk ve idaresi savunulmuştur ${ }^{70}$. Hayek planlamacılığı savunanların ekonomik hayatın daha karışık hal aldığı, rekabetin bunu karşılamaya el vermediği iddiasına karşılık, karmaşıklık ve meselelerin bütününe nüfuz edilebilmenin planlamacılıkta daha zor olduğunu söyler. $\mathrm{Bu}$ nedenle planlamacılığı - merkezileştirilmiş ekonomiyi - değil, âdem-i merkeziyetçiliği gerekli görür. $\mathrm{Bu}$, devlet faaliyetlerinin merkezden yerele indirgenmesi demektir. Yoksa devletin tamamen dışlandığı anlamına da gelmez ${ }^{71}$.

64 Hayek, Kölelik Yolu, s. 64-69.

65 Hayek, Kölelik Yolu, s. 65-66.

66 Hayek, Kölelik Yolu, s. 65-66; Ayrıca bkz. Bkz. Yayla, Hayek’in Fikir Dünyasında Liberalizm, s. 20; Hayek, Liberal Bir Sosyal Düzenin İlkeleri, s. 90.

67 Hayek, Kölelik Yolu, s. 65-66. Ancak devlet özel teşebbüslerce yapılacak bir faaliyet alanına girmemelidir. Devlet, yalnızca özel teşebbüsün çeşitli nedenlerle faaliyette bulunmadığı alanlarda hizmet sunmalıdır. Bu hizmetler ise merkezi otoritelerce değil, mümkün olduğu ölçüde yerel yönetimlerce sunulmalıdır. Bkz. Bkz. Yayla, Hayek’in Fikir Dünyasında Liberalizm, s. 20.

68 Hayek, Kölelik Yolu, s. 108. Hayek’e göre, iktidarın anlık emirleriyle yönetilen toplumlar hür değildir. Hürriyet ancak, sonuçları öngörülebilen, genel ve soyut kurallarla yönetilen toplumlarda mümkün olabilir. Bkz. Ronald Hamowy, “Friedrich A. Hayek”, Çev. Atilla Yayla, Hayek’in Liberalizm Anlayışı (İçinde), 1. Bs., Kesit Yayınları, İstanbul 2012 , s. 29.

69 Hayek, Kölelik Yolu, s. 108.

70 Hayek, Kölelik Yolu, s. 43.

71 Hayek, Kölelik Yolu, s. 77-78; devletin bütün sosyal ve ekonomik faaliyetlerden dışlanması mümkün değildir. Ancak 
Zira liberal düşüncede serbest rekabet, kuralların önceden ve soyut olarak belirlenmesi bağlamında planlamacılığın aksine bireylere serbest hareket alanları sunar. Kaldı ki liberal düşüncenin kendisi dahi dogmatik değildir ve farklı görünümlerle uyumludur. Bu yaklaşım açısından önemli olan serbestliğin ve rekabetin korunması; zorlayıcılığın - müdahaleciliğin - dışlanmasıdır ${ }^{72}$. Hukukun, düzeni bu kapsamda sağlaması beklenir. Hayek, planlamacılığın serbestliği ortadan kaldıracağını savunarak, hukukun yönetimi altında kimsenin korunmadığı ya da başkasının tercih ya da iyilerinin başkasına dayatılmadı̆̆ı bir hukuk ve toplum düzenini gerekli görür. Ona göre satımı meşru malları herkes alıp satabilmeli, fiyat serbest olmalı, herkes dilediği işte çalışabilmelidir ${ }^{73}$.

Planlamacılara göre, herkesin kendi amaçlarının peşinden gitmesinin engellenmesi toplumsal menfaatlerin korunması ve herkesin bu amaca sevk edilmesinin ekonomik ve sosyal gelişmeler bakımından nice faydaları vardır. Ancak Hayek'e göre, hürriyete karşı yapılan zorlamalar ve yasaklamalar büyük faydalar sağladığı gibi zarar da vermiyor olsa dahi gelecek açısından hürriyet rejimine sadık kalınmalıdır ${ }^{74}$. Zira adil olduğu düşünülen bir heyete veya kişiye tüm yetkiler verildiği zaman insanların tüm hakları o kişinin eline geçer ve bir gün o kişi ya da kişilerin baskı kuracağı korkusu bireylerin her an aklında yer tutar ${ }^{75}$. Dolayısıyla hürriyetten fedakârlık yapılmasıyla sınırlama kapısı açıldığı zaman artık kapatmak çok zor olacağından, hürriyet rejiminden asla taviz verilmemelidir. Hayek’e göre, zarara uğramak pahasına (ekonomik veya eşitlik yönünden) otonomiyi ve hürriyet rejimini korumak gerekir. Zira hiçbir eşitlik söylemi ve ekonomik gelişme, hürriyeti feda etmeye değmez. Hürriyetimizi korumak istiyorsak da bunun bedelini ödemeliyiz ${ }^{76}$.

Nihayet birey hiçbir kontrol mekanizması olmadan kendi eylemlerini belirleyebilmelidir. Bu bakımdan kişinin seçim yapabilmesi, yine kanaatimizce paralel olarak irade hürriyeti, oldukça önemlidir. Bazen seçme hürriyetimizi korumak pahasına yüksek bedeller ödememiz gerekse de, Hayeke göre "hürriyet" daha sonraki gelişmelerin kaynağıdır. Uzun vadede gelişim bu serbestliğe ve çeşitliliğe bağlıdır. Yine de her zaman, hürriyet gelişme doğurur demek değildir. Ancak düşünüre göre, hürriyetin faydası gelişim alanını her zaman hazır ve açık tutmasıdır ${ }^{77}$. Yani hür bireyler her zaman yeni girişim ve tecrübeleri korkusuzca gerçekleştirebilirler. Nitekim Hayek’e göre bilimsel gelişmeler ve düşünce hürriyeti, ancak kişilerin düşüncelerini açıç̧a ifade edebilmesine bağlıdır. Dolayısıyla bireyler farklı görüş ve bilgilerle

mümkün olduğu kadar özel teşebbüslerin faaliyet alanına girilmemeli ve devletin müdahil olduğu durumlarda da olabildiğince yerel yönetimler ön plana çıkarılmalıdır. Bu hususta bkz. Bkz. Yayla, Hayek’in Fikir Dünyasında Liberalizm, s. 20-21.

72 Hayek, Kölelik Yolu, s. 39. Adaletin sağlanması adına dağıtıcı adalet, kimi liberallere dahi cazip gelmektedir. Ancak böyle bir adalet anlayışının planlamacılığı gerektirdiği bir gerçektir. Oysa hürriyet düzeni veya kendiliğinden düzen müdahale ve planlamacılıkla bağdaşmaz. Onun yerine bu düzenin korunabilmesi için tek bir ihtiyaçlar hiyerarşisi ya da düzeni değil, çeşitli ihtiyaçların ve amaçların korunması gerekir. Bunun aksi bireyleri, planlamacılık içerisinde otoritenin emirlerine itaat etmeye mecbur kilar. Bkz. Hayek, Liberalizm, s. 64.

73 Hayek, Kölelik Yolu, s. 62-63.

74 Hayek, Kölelik Yolu, s. 82.

75 Dolayısıyla hiçbir siyasi iktidar güvenilir değildir. Bu hususu ilk kez Lord Acton, “Güç yozlaştırır, mutlak güç mutlaka yozlaştırır" ("Power tends to corrupt, and absolute power corrupts absolutely"), şeklinde ifade etmiştir. Konuya ilişkin bkz. Brian Martin, "Power Tends to Corrupt", Philosophy and Social Action, C. 16, S. 3, Y. 1990, s. 3-5; Lord Acton ve ifadesi için bkz. https://www.phrases.org.uk/meanings/absolute-power-corrupts-absolutely.html (E. 16.04.2019); Keskin, s. 61.

76 Hayek, Kölelik Yolu, s. 82.

77 Hayek, Kölelik Yolu, s. 82. 
karşılaşabilmelidirler. Sonuç olarak, bireylerin serbestliği düşünce dünyasının temelini teşkil eder. Buna karşılık planlamacılık, aklı da planlayarak geliştirmeye çalışır, ancak bunu yaparken aslında aklı geliştirmek yerine onu köreltir. Düşünüre göre, aklın gelişimi sosyal bir sürece bağlıdır. Bu sosyal süreç kişilerin serbestçe tartışabilmelerini ifade eder $^{78}$. Bu kapsamda hukukun üstünlüğü, birey hürriyetinin güvencesidir.

\section{Hayek'te Hukukun Üstünlüğü ile Planlamacılık}

\section{Genel Olarak}

Hayek yaşadığı dönemde İngiltere’de ekonominin devlet kontrolüne alınması gerektiği ve bu sayede sosyal adaletin sağlanacağı düşüncelerine karşı güçlü mücadeleler vermiştir. Çalışmalarında iktisadi hürriyetin sosyal ve ekonomik gelişmeler ile bireysel hürriyetlerin teminatı ve temeli olduğunu önemle vurgulamıştır. Ancak dönemi içerisinde Hayek’in görüşleri kimilerince beyhude bir çaba olarak değerlendirilmiştir. $\mathrm{Ne}$ var ki onun bu konudaki görüşleri, zamanını aşmıştır ve bugün dahi dikkate alınmaya değer niteliğini korumaya devam etmektedir. Çalışmanın bu kısmında Hayek’in hukukun üstünlüğü ve planlamacılık eksenindeki görüşlerini özellikle "Kölelik Yolu” isimli eseri rehberliğinde değerlendirerek, merkezileştirilmiş bir ekonomi düzeninde hukukun üstünlüğünün konumunu inceleyeceğiz.

\section{2. 'Planlamacı' Bir Devlette Hukukun Üstünlüğü Anlayışının Olabilirliğine Dair}

Hayek’e göre bir hukuk düzeni kurup, üretimi ferdi teşebbüse bırakan sistemle, üretimi merkezi otoriteye bırakan sistem arasındaki fark, hukukun hakimiyeti ile keyfi idare sistemi arasındaki farkın özel bir görünümüdür ${ }^{79}$. Hayek bunu ayrıca açıklar. İlk seçenekte mevcut kaynakların hangi şartlarda işletilebileceğini iktidar tespit eder. Ancak kaynakların hangi amaç için kullanılacağını kararlaştırmak bireylerin hakkıdır. İkinci seçenekte hükümet üretim vasıtalarının belli amaçlar için kullanımını emreder ${ }^{80}$. İki seçenek arasında fark bağlamında diğer kıstasa göre, hukuk rejiminde sabit kaideler konulur. Bu kuralların kimin menfaatine olduğu, ikinci seçeneğin aksine birinci seçenekte, belli değildir. Yani kanunlar, belli bir grubun yararına olacak şekilde özel çıkarılmamıştır. Kanunlar özel ihtiyaçların tatminine ve kuralların somut amaçlara yönelmesine hizmet etmez ${ }^{81}$.

78 Hayek, Kölelik Yolu, s. 215. Müdahalenin bulaşıcı bir süreç olduğu unutulmamalıdır. Bir alana yapılan müdahalenin başka alanlara yayılmasının önünde herhangi bir engel yoktur. Bkz. Yayla, Hayek’in Fikir Dünyasında Liberalizm, s. 13. Bu bakımdan açı fikirlilik, ancak bireylerin müdahaleden korunması halinde gerçekleşebilir. Bilginin keşfi de bireylerin açıkça kendilerini ifade edebildiği durumlarda ortaya çıkabilir. Dolayısıyla gelişim, bu bilgi akış sürecine bireyin dahil olduğu oranda geçekleşebilir. Bkz. Hayek, Liberalizm, s. 75.

79 Hayek, Kölelik Yolu, s. 108-110; Hayek, The Road to Serfdom, s. 75-78. Hürriyetin varlığı özel mülkiyetle anlam kazanır. Özel mülkiyet veya hürriyetlerden birisinin eksikliği diğerini anlamsız kılar. Bu bakımdan birey, piyasa içerisinde serbestçe teşebbüste bulunabilmeli, baskıya maruz kalmadan mülkiyeti üzerinde tasarruf yetkisini kullanabilmelidir. Devletin bireye müdahalesi ise ancak çoğulculuğu ve herkesin hürriyetini korumayı sağlamaya yönelik olmalıdır. Aksi halde devlet mülkiyeti kontrol ederse hürriyeti ortadan kaldırır. Bu bakımdan bireylerin kendi amaçlarına sahip olması ve serbestçe teşebbüste bulunabilmesi korunmalıdır. Bkz. Yayla, Hayek’in Fikir Dünyasında Liberalizm, s. 14-15.

80 Hayek, Kölelik Yolu, s. 108-110; Hayek, The Road to Serfdom, s. 75-78.

81 Hayek, Kölelik Yolu, s. 108-110; Hayek, The Road to Serfdom, s. 75-78; Ayrıca bkz. Hayek, Liberalizm, s. 63-67; Hayek, Liberal Bir Sosyal Düzenin İlkeleri, s. 86. 
Hayek'e göre kolektivizm-planlı iktisat hukuk rejiminin tamamen zıddıdır. Dolayısıyla devlet müdahaleleri hukukun üstünlüğüyle bağdaşmaz ${ }^{82}$. Nitekim planlayıcı, ilan edilen genel kurallarla kendini sınırlamaz. Planlayıcı halkın ihtiyaçlarından acil olanları ilk olarak seçmek suretiyle ihtiyaçları karşılamayı amaçlar. Bunu yapabilmek için de bir ihtiyaçlar hiyerarşisi kurmak ve farklı ihtiyaçlar arasından tercihte bulunmak zorundadır ${ }^{83}$. Örneğin işletilecek madenleri seçmek, işletilecek otobüs sayısını belirlemek, ayakkabı fiyatını belirlemek gibi irili ufaklı tüm üretim ve hizmet konularını düzenlemesi gerekir. Bu gibi konularda genel kural konulamayacağından bunlara ilişkin önceden karar almak da, Hayek'e göre oldukça zordur. Bu nedenle düşünüre göre, böyle durumlarda önceden kural konulamadığından çoğu kez anlık karar almayı gerektiren hallerde - yapılacak tercihler birilerinin menfaatine diğerlerinin zararına sonuçlar doğurur. Böyle bir farklılaşma ise yeni bir - ayrıcalıklı - sınıfın doğuşuna yola açar ${ }^{84}$.

Hayek, bu iddialarını şu şekilde ispata kalkar: ilk olarak, hukukun üstünlügünde devlet sadece genel durumlara genel kurallar koyar. Bu durumda devlet bireylerin amaçlarını ve tercihlerini yönlendiremez ${ }^{85}$. Bireyler önceden belirlenen kurallar çerçevesinde planlarını tatbik edebilir. Oysa devlet bireyi belli amaçlara sevk eder ve onları zorlarsa, devlet tüm amaç ve şartlar kapsamında idari eylemleri önceden bilemediği için ilan da edemez. Çünkü çoğu kez bilgiler anlık gelişmelere bağlıdır. Dolayısıyla devlet müdahaleciliğini artırdıkça bireylerin de serbest hareket etme alanı daralır ve bireyler plan yapamaz hale gelir ${ }^{86}$.

İkinci olarak Hayek'e göre, devlet her şeyi planlıyor ve gayri şahsi girişimler yerine her şeyi tasarlıyorsa bireylere tercih yani seçme hakkı tanımıyor demektir. Tüm alanları önceden planlayan devlet, neticelerini öngörebildiği hallerde kendisi bazı tercihler yapmıştır. Hemen her konuda tercihleri belirleyen devlet olunca da hukukun üstünlügünün sağladığı hürriyet düzeninin aksine merkezileştirilmiş düzende devletin mesele ve taraflar arasında tarafsı kalması beklenemez ${ }^{87}$. Çünkü devlet belli amaçların gerçekleşmesini bizzat hedeflemektedir. Bu durumda Hayek amacın gerçekleşebilmesi için devletin, kişilere bu amaçları zorla kabul ettirme ve kişileri kendi tercihlerinden vazgeçirme yoluna gideceğini belirtir. Kanunlar da bu tür rejimlerde belirlenmiş hedefleri gerçekleştirmek için bir baskı aracı halini alır. Böyle olunca da devlet insanın korunması ve gelişimi için kurulan bir yapı olmaktan çıkar ${ }^{88}$. Bunun aksine devlet ve onun tercihleri amaç halini alır. Dolayısıyla Hayek, Nazi devleti gibi kolektivist devletlerde devletin kendi iyilerini, yani ahlaki ya da gayri ahlaki olarak belirlediklerini bireylere dayatırken, liberal devletlerin ise böyle olmadığını

82 Ayrıca bkz. Aktaş, Aktaş, Hayek'in Hukuk ve Adalet Teorisi, s. 170.

83 Hayek, Kölelik Yolu, s. 110.

84 Hayek, Kölelik Yolu, s. 110; Hayek, The Road to Serfdom, s. 85. Kuşkusuz birilerinin durumunun iyileştirilmesi ve onların konumlarının yükseltilmesi demek, diğer başka grupların konumlarındaki olası değişiklikleri önlemeye de yol açar. Bkz. Hayek, Liberal Bir Sosyal Düzenin İlkeleri, s. 102-103. Hayek, ayrıca, örgütlü grupların, menfaat gruplarının, mal ve hizmetlerinin miktarına karar verme yetkisiyle donatılmasının toplumun çıkarına aykırı olacağını belirtir. Bkz. Hayek, Özgür Bir Toplumun Siyasi Düzeni, s. 137 vd.

85 Hayek, Kölelik Yolu, s. 112; Bkz. Yayla, Hayek’in Fikir Dünyasında Liberalizm, s. 12.

86 Hayek, Kölelik Yolu, s. 112; Hayek, The Road to Serfdom, s. 75-77.

87 Hayek, Kölelik Yolu, s. 113; Hayek, The Road to Serfdom, s. 75-77.

88 Hayek, Kölelik Yolu, s. 113. 
belirtir. Daha açık bir ifadeyle liberal devlet, bir iyiler manzumesi benimseyip bireyleri kontrol ederek onlara bu iyileri dayatma yoluna gidemez ${ }^{89}$.

Bireylerin hürriyet alanını koruma amacına sahip olan hukukun üstünlüğü, herkesin kanun önünde eşitliği esasına dayanır. Ancak planlamacılık söz konusu olduğu zaman kim, neye sahip olabilir, insanların serveti ne olabilir veya ne olamaz gibi bütün ekonomik konular kanunla düzenlenir. Tüm ekonomik faaliyetlerin kanunla düzenlenmesi de düşünüre göre, imtiyazlıların ortaya çıkmasına neden olabilir. Oysa bu hukukun üstünlüğünün gereği olan eşitliğe aykırı olacağından hukukun üstünlüğüyle tamamen ters düşer ${ }^{90}$. Zira kanunları yapan organlar, siyasi organlar olduğu için menfaat çatışmasının çıkması kaçınılmazdır ve bu siyasi organların tarafsız kalması ancak bir hayal olabilir.

Bu bağlamda, kanun önünde eşitlik yerine maddi eşitliği sağlamaya yöneldiği ölçüde Hayek’e göre devlet, hukukun üstünlügünü yok etmeye başlar. Her ne kadar hukukun üstünlügü eşitsizliklere yol açabilecek olsa da belli kişileri belli şekilde mağdur etmekten - birilerinin tercihlerini öncelemekten - uzaktır ${ }^{91}$. Gerek bugün gerekse Hayek'in döneminde mülkiyet edinme yalnızca bir gruba özgülenmemiştir. Genel kurallar çerçevesinde herkes mülk edinebilir. Ancak buna herkesin muvaffak olması beklenemez. Kimi zengindir, kimisi değil; kimi miras yoluyla mülk edinirken kimine ise miras kalmaz ${ }^{92}$. Kaldı ki bu durum yoksul olanların diğerleri karşısında zenginleşmesi ve mülkiyet sahibi olanların mallarının yeniden dağıtımı bakımından hukukun konusu olamaz. Diğer taraftan kimilerinin mülkiyet edinmesi hususundaki muvaffakiyeti Hayek’e göre, bir imtiyazlı sınıf oluşturmaz. Zira herkes mülk edinebilmek bakımından eşittir; fakir olan da mülk edinebilir. Oysa üretim ve tüketimin idare tarafından belli kişilerce yapılabileceği düzenlenmişse ya da özel mülk edinme hakkı sadece bir gruba tanınmışsa burada imtiyaz vardır ${ }^{93}$. Belli bir grubun mülk edinebileceği açıcça düzenlenmemiş olsa bile siyasi iktidar çoğu kez bazı menfaat gruplarını diğerlerine tercih eder. Tüm ekonomik faaliyetleri sevke muktedir olanların, er ya da geç bu yetkilerini kötüye kullanacağından da şüphe yoktur ${ }^{94}$.

89 Hayek, Kölelik Yolu, s. 111. İngiliz geleneği çerçevesinde devletin adil davranış kurallarıyla sınırlandırılması nedeniyle iktidarın/devletin bireyin ekonomik faaliyetlerini kontrol etmesi mümkün olmaz. Hukukun üstünlüğü de, hürriyetin korunması ile ekonomik hürriyetlerden bağımsız değildir. Bkz. Hayek, Liberalizm, s. 52.

90 Hayek, Kölelik Yolu, s. 116. Liberalizm, herkesin hür olmasını gerekli görür. Hukukun hürriyete müdahalesinin amacı da yalnızca herkesin hürriyetinin korunması olmalıdır. Bu eşitlik anlayışına da "eşit hürriyet ilkesi” denir. Bkz. Yayla, Hayek'in Fikir Dünyasında Liberalizm, s. 11-12. Dolayısıyla liberal hürriyet anlayışı, hukukun korumasında herkesin aynı şekilde hür olması demektir. Bkz. Hayek, Liberalizm, s. 52-53.

91 Hayek, Kölelik Yolu, s. 116. Hürriyet düzeni, maddi eşitliği sağlamayı amaçlamaz. Çünkü bütün bireylerin başlangıç anından itibaren eşitlenmeye çalışılması tasarlanmış bir düzeni gerektirir ki bu düzen hürriyetle bağdaşmaz. Hürriyet düzeni veya liberalizm ancak bireylerin şekli eşitliğini, yani din, dil, ırk gibi esaslara dayalı ayrımcılıkları ortadan kaldırmaya çalışır. Bu sosyal engelleri ortadan kaldırmayı, herkes için gerektirir. Bkz. Hayek, Liberalizm, s. 66.

92 Ayrıca bkz. Hayek, Kölelik Yolu, s. 117. Bu bakımdan liberalizmin ve hukukun üstünlüğ̈nün herkese bazı sonuçları ve başarıları garanti etmesi kesinlikle beklenemez. Ancak liberal hürriyet anlayışının amacı, bireylerin önlerine çıkan beşerî engellerin ortadan kaldırılmasıdır. Ayrıca bkz. Hayek, Liberalizm, s. 54; Hayek, Liberal Bir Sosyal Düzenin İlkeleri, s. 86.

93 Hayek, Kölelik Yolu, s. 117. Yeniden dağıtım vergilendirme yoluyla mülkiyetin ihlaline yol açarken, kanun önünde eşitliğinde ihlal edilmesine neden olur. Bkz. Hayek, Liberalizm, s. 66-67.

94 Bkz. Friedrich A. Hayek, “Liberal Bir Devletin Anayasası”, Çev. Mustafa Erdoğan, Hayek'in Liberalizm Anlayışı (İçinde), 1. Bs., Kesit Yayınları, İstanbul 2012, s. 114. Konuya ilişkin ayrıca bkz. Brian Martin, "Power Tends to Corrupt", 
Diğer yandan Hayek planlamacılıkta bebeklere verilen süt miktarı ile işçi ücretleri arasında veya işsizlere iş sağlanması ile çalışanların ücretlerinin iyileştirilip daha yüksek rakamlara çekilmesi gibi çok çeşitli alanlarda çeşitli tercihlerde bunulması gerektiğini vurgulayarak, ihtiyaçlar hiyerarşisinin kurulmasını gerektiğini sıkça vurgular ${ }^{95}$. Planlamacılığın içerisine girdiği bu duruma ilişkin de farklı çözüm yolları geliştirilmeye çalışılır. Hayek’e göre, planlamacılığın alanı genişletildikçe hukuk ilkelerinin yerine, meselelerin adil ve makul olup olmadığını teste yarayan formüllerin ortaya çıkması söz konusu olur. Bu durumda idare ve mahkemelerin yetkilerinin de genişleyeceğini söyler. Düşünür böyle bir değişimin hukukun üstünlügünün kaybolduğuna işaret ettiğini belirtir ${ }^{96}$. Zira planlama yapabilmek, planı uygulayabilmek ve aynı zamanda kanunun iktisadi hayatı sevk ve idare edebilmesi için beklenmeyen şartlarda karar verilebilmesi, devlet organlarına geniş yetkilerin verilmesini gerektirir. Bunun sonucunda da kimi zaman yasama yetkisinin bakanlıklara ve idari makamlara devredilmesi gerekir ${ }^{97}$.

Her şeyin merkezden planlandığı durumlarda devletin düzenlemesi ve dikkate alması gereken olasılıklar o kadar artmış ve teknik konular o kadar çoğalmıştır ki kanunların bu olaylara uygulanabilmesi, Hayek’e göre yetersiz hale gelir. Diğer bir ifadeyle meseleler genel kurallarla çözülemez olur. Bu nedenle asıl mesele yasama yetkisinin devrinden daha geniş bir soruna neden olur $^{98}$.

Hayek’e göre, demokratik meclisler planlamacılı̆̆ın her meseleyi enine boyuna incelemeyi gerektirmesine yetişemezler. Teknik konularda yetersiz kalırlar, ayrıca kimi durumlarda genel kurallarla değil anlık emirnamelerle karar almak gerekebilir ${ }^{99}$. Bu durum ise yasama yetkisinin uzmanlara/veya bir makama devri gibi durumlara yol açabilir. Çünkü her meseleyi bilemeyen, teknik yetersizlikleri nedeniyle hatalı kararlar veren bir yasama organına karşı halkın da güveni azalır ${ }^{100}$.

Philosophy and Social Action, C. 16, S. 3, Y. 1990, s. 3-5; Lord Acton ve ifadesi için bkz. https://www.phrases.org.uk/ meanings/absolute-power-corrupts-absolutely.html (E. 16.04.2019); Keskin, s. 61. Devletin iktisadi faaliyete kalkışması halinde sahip olduğu üstünlük ve ayrıcalıklar sayesinde zorlayıcı yetkilerini ve en etkili olarak da vergilendirme yetkisini kullanmak suretiyle diğer işletmeler karşısında avantaj sağlayarak kendi işletmesini tekel haline getirebilir. Dolayısıyla Hayek devletin ticari faaliyette bulunmasına karşı değildir. Onun karşı olduğu ve asıl tehlikeli olarak değerlendirdiği, devletin kontrolünün dar sınırlar içerisinde kalmayıp ekonomik faaliyetlerin büyük bir kısmını kontrol altına alması ve devlet tekellerinin ortaya çıkmasıdır. Bkz. Hayek, Özgürlüğün Anayasası, s. 338-339. Çoğunluğun yönetiminin sınırlandırılmadığı hallerde de benzer şekilde menfaat gruplarının genel menfaat yerine, özel menfaatleri takip edeceğine dair ayrıca bkz. Hayek, Liberalizm, s. 68-69.

95 Hayek, Kölelik Yolu, s. 115.

96 Hayek, Kölelik Yolu, s. 115.

97 Hayek, Kölelik Yolu, s. 121.

98 Hayek, Kölelik Yolu, s. 100.

99 Hayek, Kölelik Yolu, s. 96-97. Hayek emirlerle kanunları birbirinden ayırt eder. Ona göre emirler geniş anlamıyla kişilerin davranışlarını yönetmeleri bakımından ele alındığında kanunların da emir niteliğini haiz olduğu söylenebilir. Ancak düşünür, genel kuralların emirlerden farklı olarak, bir yapıcısının olmasının gerektiğini belirtir. Bu bağlamda kanunlar/ genel kurallar, emirlerden farklı olarak genellik ve soyutluk bakımından ayrılır. Hayek, genel ve soyutluk derecesinin farklı emirlere ve buyruklara göre de değişebileceğini söyler. Bkz. Hayek, Özgürlüğün Anayasası, s. 235-236.

100 Hayek, Kölelik Yolu, s. 96-97. Eğer demokrasi liberal ilkeleri koruyamazsa Hayek’e göre kendi varlı̆̆ı da tehlikeye girer. Zira demokrasi eliyle ekonominin merkezileştiği durumlarda bu gelişim otoriterleşmeyi gerektirir. Bkz. Hayek, Liberalizm, s. 69. 
$\mathrm{Bu}$ nedenle uzmanlardan oluşan kurulların, planlamacılığa dair teknik ve ayrıntılı hususları incelemesi gerekli görülür. Ancak her konuda farklı uzmanların fikirleri ve planları bir bütün haline sokulmaya muhtaç olduğundan yetkilerin bir kısmının uzmanlara verilmesi de bir tür belirsizliğe ve karışıklığa yol açar ${ }^{101}$. Bu durumda planlamacılık taraftarları için bu meselenin çözümü elinde tüm yetkileri tutan demokratik usullerle belirlenmemiş bir kuvvetin varlığıdır. Dolayısıyla planlamacılık taraftarları eninde sonunda demokratik yolların neden olduğu engellerden kurtulmaya çalışırlar. Hayek'e göre bu ekonomik diktatörlük, planlamacılığın bir safhasıdır ${ }^{102}$.

Hayek'in üzerinde durduğu gibi merkezileştirilmiş bir ekonominin varlığının, yani planlamacılığın söz konusu olduğu bir devlette hukukun üstünlügünün olmadığını belirtmenin yanı sıra, böyle bir devlette hukukun üstünlüğü olmaz demenin kanunun da olmayacağı anlamına gelmediğini belirtmek gerekir ${ }^{103}$. Burada hukukun üstünlügünün olmayacağının anlamı, hükümetin kanunla sınırlandırılamaz olduğudur. Zira hukukun üstünlüğünden söz edildiğinde iktidarın ancak önceden belirlenen hallerde ve belirlenen yetkileri kullanabileceğinin, yani yetkilerinin sınırlı olduğunun anlaşılması gerekir ${ }^{104}$. Oysa planlamacılık adına bakanlıklara, idareye, her konuda yetki veren bir kanun olsa ve bu kurumlar kanuna göre hareket etmiş olsa dahi bu devlet işlemlerinin hukukun üstünlügüne uygun olduğunu göstermez. Görüleceği üzere yürütmenin eylem ve işlemleri şekli anlamda belli nitelikleri haiz bir kanuna uygun olmuş olsa dahi, bu hukukun üstün olduğu anlamına gelmez. Hayek’e göre hukukun üstünlügünden söz edebilmek için kanunların iktidarı belirli konularda sınırlandırması gerekir. Hayek'in bu konuya ilişkin örneği ise Hitler'dir. Bu bağlamda düşünür, Hitler’in kullandığı yetkiler anayasaya ve kanuna uygun olsa dahi o günün Almanyasında hukukun üstünlüğü vardır denilebilir mi sorusunu sorar ${ }^{105}$.

Hayek planlamacılığı savunanlarının, rekabetçiliğin sonunun gelmiş olduğunu ve yeni teknik gelişmelerin varlı̆̆1 gibi nedenleri gerekçe gösterdiklerini söyler ${ }^{106}$. Düşünür, kimilerinin planlamacılığın serbestlikle sağlanamayacak kazanımlara ve gelişmelere katkı sağladığını ileri sürdügünü belirtir. Örneğin 20. yüzyılın ilk yarısında Alman otoyollarının eşsiz, geniş ve pürüzsüz yollar olduğu ileri sürülmüştür. Ancak Hayek, bunun liberal toplumda olmasını engelleyen bir nedenin olmadığını belirterek, ayrıca Almanya’nın methedilen yollarında, İngiltere'deki kadar

101 Hayek, Kölelik Yolu, s. 93-101.

102 Hayek, Kölelik Yolu, s. 93-101. Diktatörlük, genel ve soyut kurallar yerine anlık-öngörülemez emirlerin veya kişileri belli amaçlara zorlayan kuralların hâkim olduğu aşamadır. Konuyu bu açıdan değerlendirirken Hayek’in emirlere yüklediği anlamın da göz ardı edilmemesi gerekir. Zira Hayek’e göre, emirler genel kuralların aksine kişilerin kendilerine ait bilgileri kullanmasının ve kendi tercihlerini takip etmesinin önündeki engeldir. Emirler ancak onları çıkaran kişi ya da grupların kendi amaçlarına hizmet eder. Bkz. Hayek, Özgürlüğün Anayasası, s. 236.

103 Hayek, Kölelik Yolu, s. 120. Buradan da her kanun isimli düzenleyici işlemin hürriyetleri korumayacağı anlamı ortaya çıkmaktadır. Ayrıca bkz. Hayek, Liberalizm, s. 55-56.

104 Hayek, Kölelik Yolu, s. 120-122; Ayrıca bkz. Hayek, Liberalizm, s. 55-56.

105 Hayek, Kölelik Yolu, s. 120. Hayek burada yasama organının kanunlarıyla yürütmeye her türlü yetki verilebileceğiyle uyumlu olan Rechtsstaat’ın hukukun üstünlüğünden ayrıldığını göstermektedir. Bkz. Hayek, Liberal Bir Sosyal Düzenin İlkeleri, s. 90.

106 Hayek, Kölelik Yolu, s. 71-72. Bu söylem çerçevesinde liberalizmin, dolayısıyla liberal hürriyet anlayışının gerilemesi olarak Birinci Dünya Savaşı sonrası gelişmeler ve sosyal adalet-politika amaçları etkili olmuştur. Bkz. Hayek, Liberalizm, s. 49-51. 
otomobil olmadığını da söyler ${ }^{107}$. Yine de şu bir gerçektir ki, planlamacılığın ortaya koyduğu idealler - hedefler-, çoğu kişi tarafından benimsenecek türdendir. Bununla birlikte planlamacılık adına sorun ve tehlike, bu amaçların elde edilmesinde kullanılacak metotlardır ${ }^{108}$. Diğer bir ifadeyle çoğu kişi, sosyal refah, adil ücret, herkesin istihdam edilmesi gibi hedeflere ilk etapta karşı çıkmayabilir. Ancak bu hedeflerin gerçekleştirilmesi noktasında planlı bir ekonomide devletin yetkilerinin aşkın hale bürünmesi ise çoğu zaman planlamacılık destekçileri tarafından bile kabul görmez. Nitekim Hayek de planlama yapan merkezi otoritenin elindeki yetkilerin tehlikeli şekilde sınırsız hale geleceğini belirtir ${ }^{109}$. Hayek tüketimi karşılayacak bir ekonomi ve kazancın yeniden dağıtımı meselelerinin gerçekleştirilebilmesi ile, bir ırkın, parti veya menfaat grubunun çıkarlarının korunup onlara fazladan hisse ayrılmasının da aynı metotlarla sağlanabileceğini ifade eder ${ }^{110}$. Kanaatimizce düşünür, aslında burada kullanılan metotların aynılığı nedeniyle, planlamacılığın kötü niyetlilerce suiistimal edilebileceğini veya iyiniyetli planlamacıların da bir gün ellerindeki yetkileri menfaatleri lehine kullanmaya başlayacağını kasteder.

Diğer taraftan plancılığın neden olduğu anlık emirlerle somut durumlara göre alınan kararlara ve kanunların belli somut hedeflere yönelmesine karşılık, liberal bir sistem genel ve belirli kanunların hususi - somut - etkileri önceden tespit edilemez ${ }^{111}$. Örneğin devlet inşaat yapımına veya fabrikalara ilişkin kanun çıkarmışsa bu kanun belli kişilerin lehine ya da aleyhine hareket etmeyi amaçlamadığı müddetçe, devletin bu tür faaliyetleri liberalizmle ters düşmez ${ }^{112}$. Dolayısıyla hukukun üstünlüğü bağlamında devletin genel olmayan kurallarla hususi amaçlara yönelmesi kesinlikle uyumsuzdur ${ }^{113}$. Öte yandan yine planlı devletin aksine liberal devlet, hareketsizdir. Ancak Hayek devletin bu hareketsizliğinin tamamen "bırakınız yapsınlar (laissez faire)" olarak görülemeyeceğini ifade eder.

107 Hayek, Kölelik Yolu, s. 84.

108 Hayek, Kölelik Yolu, s. 58-59.

109 Hayek, Kölelik Yolu, s. 82-83. Bu bakımdan devletlerce, örneğin, tam istihdamı sağlamaya kalkışılması ve buna paralel olarak sendikal faaliyetler nedeniyle ücretlerin sürekli artırılması da enflasyona yol açar. Bu süreç fiyatların merkez tarafından belirlenmesini beraberinde getirir. Dolayısıyla kimi masum görünen amaçlar aslında istenmeyen sonuçları beraberinde getirmektedir. Bkz. Hayek, Liberalizm, s. 74 .

110 Hayek, Kölelik Yolu, s. 59; Hamowy, Friedrich A. Hayek, s. 28-29; Ayrıca bkz. Hayek, The Road to Serfdom, s. 34.

111 Hayek, Kölelik Yolu, s. 118; Yayla, Hayek'in Fikir Dünyasında Liberalizm, s. 12. Her düzenleyici işlem hukukun üstünlüğünü sağlamaya yetmez. Ancak Rechtsstaatın farkı da burada ortaya çıkar. Zira Alman Rechtsstaat formülü kuralların yalnızca usulünce çıkarılmasıyla ilgilenir. Kuralların içeriği ya da iktidara sınırsız yetkiler vermesi önemli değildir. Bkz. Hayek, Liberal Sosyal Bir Düzenin İlkeleri, s. 97. Kanun ile emirlerin arasındaki farka ilişkin ayrıca bkz. Hayek, Liberal Bir Devletin Anayasası, s. 112-113.

112 Hayek, Kölelik Yolu, s. 118-119. Hayek’e göre, liberal devlet tamamen hareketsiz kalamaz. Devlet ölçülerin denetlenmesi, dolandırıcılığın ve hakların kötüye kullanılmasının önlenmesi gibi bazı faaliyetlerde bulunmak zorundadır. Örneğin, grevcilerin veya eylemcilerin şiddete başvurmalarına sessiz kalan devlet ideal bir devlet değildir. Dolayısıyla Hayek’e göre belli durumlarda edimde bulunması gerektiği halde hareketsiz kalan devlet liberal ilkelere aykırı davranmış olur. Zira hukukun üstün olduğu, ya da diğer bir ifadeyle hukukla yönetilen bir devlet, bireyleri yalnızca kendine karşı değil, diğer kişilere karşı da korur ve bireylerin hak ve hürriyetlerini kullanmasını destekler. Bkz. Hayek, Kölelik Yolu, s. 118. Diğer bireylerden gelen engellerin kaldırılmasının liberal hürriyet anlayışının esasını oluşturduğuna dair bkz. Hayek, Liberalizm, s. 54.

113 Hukukun üstünlüğü yasamayı sınırlar belli kişilerin yararına-zararına göre hareket etmeyi men eder, herhangi makamın kişiler arasında ayrım yapmasını önler. Hukukun üstünlüğü her şeyin kanunla düzenlenmesi demek değildir, siyasi iktidarın/devletin zorlama iktidarının kanunla düzenlenmiş olduğu hallerde ve önceden bilinmesi şartıyla yetkilerini kullanmasını ifade eder. Dolayısıyla genel olmayan emirler niteliğinde kurallar hukukun üstünlüğü ile bağdaşmaz. Bkz. Hayek, Kölelik Yolu, s. 121-122; Hayek, The Road to Serfdom, s. 75-78. 
Çünkü düşünürün belirttiğine göre kuşkusuz, liberal devlet dahi bazı faaliyetlerde bulunur ve bunun da bazı sonuçları olur ${ }^{114}$. Fakat Hayek, hukukun üstünlüğü gereği olarak devletin faaliyetlerinin önceden bilinebilir olması ve bireylerin geleceğe ilişkin olarak kendi tercihlerini tatbik edebilmelerinin korunmasının gerektiğini belirtir. Bu sayede bireyler kendi özerk alanını devletin kontrolü dışında yönetebilir ve devletin bireyleri başkalarından gelebilecek saldırılara karşı ne kadar koruyabileceğini de öngörülebildiğinden bireyler, tercihlerini buna göre yönlendirir ${ }^{115}$.

\section{Hayek'e Göre Planlamacılı̆̆ın Kaçınılmaz Neticesi: Kölelik}

Hayek planlamacılığın olduğu bir devlette hukukun üstünlüğünden söz edilemeyeceğine yönelik iddialarını iki hususta açıklar. İlk olarak, hukukun hakimiyetinde devlet sadece genel durumlara yönelik genel kurallar koyar. Bu durumda devlet bireylerin amaçlarını ve tercihlerini yönlendiremez. Bireyler önceden belirlenen kurallar çerçevesinde tercihlerde bulunur ve planlarını hayata geçirebilir ${ }^{116}$. Buna karşılık devlet, bireyi belli eylemlere sevk ederse, tüm bu amaç ve şartları gerçekleştirmeye yönelik eylem ve işlemleri ilan edemez. Çünkü çoğu kez bilgiler anlık gelişmelere bağlıdır. Dolayısıyla devlet müdahaleciliği arttıkça bireylerin de serbest hareket etme alanı daralır ve bireyler plan yapamaz hale gelir ${ }^{117}$.

İkinci olarak devlet her şeyi planlıyorsa bireylere tercih yani seçme hakkı tanımıyor demektir. Her şeyi önceden planlayan devlet, neticelerini öngörebildiği hallerde kendisi tercih yapmıştır. Planlayıcı olarak devletin, hukukun üstünlügünün aksine, mesele ve taraflar arasında tarafsız kalması beklenemez ${ }^{118}$. Çünkü devlet, belli amaçların gerçeklemesini bizzat hedeflemektedir. Bu durumda, amacın gerçekleşebilmesi için kişilere söz konusu amaçları zorla kabul ettirme ve kendi tercihlerinden vazgeçirme yoluna gider. Bu tür rejimlerde ise kanunlar, belirlenmiş hedefleri gerçekleştirmek için bir araç niteliğindedir. Böyle olunca da devlet, insanın korunması ve gelişimi için gerekli bir aygıt olmaktan uzaklaşır ${ }^{119}$.

Planlamacılık, ihtiyaçların, üretimin veya adil ücret hedeflerinin gerçekleştirilmesini amaçlar. Bu bağlamda Hayek'e göre plan yapıldıktan sonra, birey, ihtiyaç hiyerarşisini belirleme iktidarından mahrum kalır. Ancak planlamacılık, yalnızca iktisadi meseleler üzerinde tesir bırakmaz. Adeta bireyin özerk alanını işgal eder ${ }^{120}$. Dolayısıyla planlayan doğrudan ya da dolaylı olarak özel hayata

114 Hayek, Kölelik Yolu, s. 118.

115 Hayek, Kölelik Yolu, s. 118.

116 Hayek, Kölelik Yolu, s. 112. Gerçekten de hür toplumda bütün amaçlar eşittir. Birilerinin amaçları, planlamacı toplumlardakinin aksine, bir diğerine tercih edilemez. Hukuk düzeni herkesin girişim ve amaçlarını korur. Herkes kendi bilgi ve tecrübesini dilediği gibi kullanabilir. Bkz. Hayek, Liberal Bir Sosyal Düzenin İlkeleri, s. 88-89.

117 Hayek, Kölelik Yolu, s. 112. Örneğin sosyal adalet söylemi altında hareket eden ve herkesin eşit ve refah içinde yaşayacağını slogan edinen bir iktidarın bunu gerçekleştirmesine yarayacak objektif ilkeler yoktur. Sosyal adaletin sağlanmasına yönelik test ya da ilkeler olmadığından iktidar sahibi kendi tercihlerine göre, diğer bir ifadeyle keyfi olarak hareket eder. Ayrıca bkz. Hayek, Liberal Bir Sosyal Düzenin İlkeleri, s. 92, 98.

118 Hayek, Kölelik Yolu, s. 113.

119 Hayek, Kölelik Yolu, s. 113.

120 Hayek, Kölelik Yolu, s. 132. 
girer, neyin daha az önemli olduğunu belirlemeye yönelik ihtiyaçlar arasında bazı tercihlerde bulunur, birey yerine kendisi ihtiyaçlar hiyerarşisi kurar. Bu girişim doğrudan üretime ve tüketime yönelik bir çaba olarak değerlendirilse de; esasında tüm hayatın kontrol altına alınması anlamına gelir ${ }^{121}$. Nitekim bu durumda Hayek, işimizi, zevklerimizi, üretimin yanında tüketimi ve amaçlarımızı da otoritenin belirlediğini belirtir. Böyle bir toplumda bireyin çaba ve amaçları anlamsız kalmıştır. Hayek planın siyasi iktidar tarafından yapılmasının, seçme hürriyetinin olmamasına yol açtı̆̆ını ve bunun da katlanılamaz olduğunu belirtir ${ }^{122}$. Bu bağlamda düşünür, planlamacılığın asıl iddiasının ve bu planları yapmasındaki maksadın bireylerin araç olmaktan kurtarılması olduğunu, ancak gerçeğin ise bireysel zevklerin ve planların hesaba katılmaması ve dikkate alınmaması olduğunu dile getirir. Zira iktidar sosyal refah ve kamu menfaati karşısında bireylerin tercihlerini göz ardı eder; nitekim onun için aslolan birey değil, toplum ve hatta plandır ${ }^{123}$.

Dolayısıyla Hayek'e göre, planlamacılık tesis edilince devlet müdahalesi sadece ekonomik hayatımıza tesir etmez. Çünkü liberal çağ boyunca bireylerin bütün yönleri başkalarının da iktisadi faaliyetlerine bağlı olarak gelişmiştir. Bu bağlamda Hayek, bireylerin hürriyetlerin zaruri şartı ve esası olarak iktisadi hürriyeti görür ${ }^{124}$. Zira o, iktisadi hürriyet terkedilince siyasi ve bireysel hürriyetin onu takip edeceğini belirtir ${ }^{125}$. Planlamacılık ile hak ve hürriyetler tam olarak bağdaşamaz. Alımsatım yasaklarının varlığı dahi buna delalet eder. Örneğin, planlamacılığı savunanlar, alım-satımın genel refaha uygun olduğu müddetçe serbest olması gerektiğine dair görüşler ileri sürmüşlerdir. Hayek'e göre ise herhangi bir sebebin, tabiat olayı, çevresel koşullar gibi nedenlerin, genel refahı etkilediği ileri sürülebilir ${ }^{126}$. Kaldı ki "genel refah" ifadesi oldukça geniş anlamlı ve muğlaktır. Ayrıca planlamacılıkta, sosyal refah, genel yarar gibi muğlak kavramlarda aslolan birey değildir. Dolayısıyla bu kavramların bireyleri koruması da pek beklenemez ve düşünüre göre, planlamacılıkta bireysel hakların korunduğundan söz edilemez ${ }^{127}$.

Hayek, planlamacılıkta bireysel hakların korunmadığına dair kâğıt tedarikinin tek merkezden yapılıyorken basın hürriyetinin nasıl mümkün olacağı sorusunu yönelterek konuyu açılamaya çalışır $^{128}$. Ayrıca Hayek’e göre Avrupa tarihinde tecrübe edilmiştir ki, iktisadi hayat kontrol altına

121 Hayek, Kölelik Yolu, s. 132 - 133.

122 Hayek, Kölelik Yolu, s. 134-136. Zira herkesin bireysel şartları ve yetenekleri farklıdır. Bu farklılık ihtiyaç ve taleplerde de ortaya çıkar. Dolayısıyla devletin bireylerce seçilen amaçları koruması ve başka bir amacı dayatmaması gerekir. Bu bireylerin başkalarının hayatlarına sunduğu en büyük katkıdır. Bu hususta bkz. Hayek, Liberalizm, s. 54.

123 Hayek, Kölelik Yolu, s. 138-139.

124 Hayek, Kölelik Yolu, s. 143-144; Ayrıca bkz. Hayek, Liberalizm, s. 76. Bu bağlam da Hayek, Antik Yunan'dan bugüne kadar mülkiyetin hürriyetlerin temeli olduğunu vurgular. Ona göre soyut kurallar olarak kanunlar, herkesin istediği zaman mülkiyeti üzerinde tasarrufta bulunmasıyla yakından ilgilidir. Bkz. Friedrich A. Hayek, "The Fatal Conceit - The Errors of Socialism", The Collected Works of Friedrich August Hayek, V. I, Ed. W. W. Bartley, Routledge, London, 1998, s. 30-31.

125 Hayek, Kölelik Yolu, s. 34; Ayrıca bkz. Hayek, Liberalizm, s. 76.

126 Hayek, Kölelik Yolu, s. 123-124.

127 Hayek, Kölelik Yolu, s. 123-124.

128 Hayek, Kölelik Yolu, s. 124. Ekonomik ve sosyal araçlar üzerinde kontrole sahip bir siyasi iktidar karşısında bireylerin hürriyetlerini kullanabilmesi oldukça zordur. Örneğin taşıtların merkezi otoritenin kontrolünde olması seyahat hürriyetinin, kâğıt üretiminin merkezi otoritenin kontrolü veya tekelinde olması ifade ve düşünce hürriyetinin, benzer şekilde park ve meydanların merkezi otoritenin kontrolünde olması ise toplantı hürriyetinin anlamsız hale gelmesine neden olur. Ayrıca bkz. Hayek, Liberalizm, s. 76. 
alınınca bireysel hakların ve azınlık haklarının şeklen tanınmasının bir anlamı kalmaz. Çünkü çoğu kez masum amaç ve araçlar gibi görünse de planlamacılık, iktidara sınırsız bir hareket alanı sağlar. İktidar ekonomi adı altında herkesin özerk alanına dokunabilir, azınlığı sindirebilir ve haklarını ihlal edebilir $^{129}$. Nitekim sosyalizm gibi planlı ekonomiyi öngören yaklaşımların amaçlarının çoğu kişi tarafından benimsenebilecek nitelikte olduğunu belirtilebilir. Düşünüre göre ise asıl sorun ve tehlike bu amaçların elde edilmesinde kullanılacak metotlardır. Zira planlamacılık araçları başkaca amaçlara kavuşmayı da sağlayacak bir niteliktedir. Örneğin, tüketimi karşılayacak bir ekonomi veya kazancın yeniden dağıtımı meselelerinin gerçekleştirilebilmesi ile bir ırkın, parti veya menfaat grubunun çıkarlarının korunup onlara fazladan hisse ayrılması da aynı metotlarla sağlanabilir ${ }^{130}$.

Tüm bu riskler, yani kazancın adil dağıtımını sağlamak isterken, örneğin parti çıkarlarının aracı haline gelme tehlikesi gibi, bazı efsunlu hayallerden fedakârlık yapmayı gerektirir. Zira seçme hürriyeti bireysel hayat için oldukça önemlidir. Bazen "seçme hürriyetimizi” korumak adına yüksek bedeller ödememiz gerekir. Bireylerin serbest seçimi, diğer bir ifadeyle seçme hürriyeti, Hayek’e göre, sonraki gelişmelerin kaynağıdır. Uzun vadede gelişim bu serbestliğe ve çeşitliliğe bağlıdır. Her ne kadar seçme hürriyeti mutlaka iyi sonuçlara ya da herkesin menfaatine katlı sağlar diyemesek de hürriyetin önemi, gelişim alanını her zaman hazır ve açık tutmasında kendini gösterir ${ }^{131}$.

Planlamacılıkta hürriyetlere karşı zorlamaların ve yönlendirmelerin olmasının büyük faydalar sağladığı ve zarar vermediği durumlar da olabilir. Ancak Hayek, gelecek açısından hürriyet rejimine sadık kalınması gerektiğini önemle vurgular ${ }^{132}$. Düşünür, hürriyetlere müdahale kapısı açıldığ 1 zaman, artık o kapıyı kapatmak çok zor olacağından, hürriyet rejiminden taviz verilmemesine, zarara uğramak pahasına otonomiyi ve hürriyet rejimini korumak gerektiğine dikkat çeker. Nitekim hiçbir gelişme hürriyeti feda etmeye değmez ve hürriyetimizi korunak istiyorsak bedel ödememiz gerekir ${ }^{133}$.

Hayek'e göre planlamacılıkla ilgili olarak diğer bir tehlike ise diktatörlüktür. Zira planlamacılıkta belirlenen amaca ulaşabilmek bir zorunluluktur. Hayek bu nedenle planlamacılığın diktatörlüğü doğurduğunu iddia eder. Ona göre, bireyin hürriyetini koruma işlevini kaybetse bile, demokrasi varlığını sürdürebilir. Hayek'e göre "proletarya diktatörlüğü” şekil olarak demokratik, ancak hürriyetleri de yok etmesi bakımından mutlakiyetten farksızdır ${ }^{134}$.

129 Hayek, Kölelik Yolu, s. 126. Ekonomiyi kontrol etmenin hürriyetleri kontrol etmek olması nedeniyle, planlamacılık veya merkezileştirilmiş ekonomilerde hürriyetlerin kısıtlanması kaçınılmaz bir sonuçtur. Bkz. Hayek, Liberalizm, s. 76-77.

130 Hayek, Kölelik Yolu, s. 58-59.

131 Hayek, Kölelik Yolu, s. 82; Ayrıca bkz. Hayek, Liberalizm, s. 76.

132 Hayek, Kölelik Yolu, s. 82.

133 Hayek, Kölelik Yolu, s. 82. Buna karşılık bunun her zaman mümkün olmadığını belirtmemiz gerekir. Orwell söz konusu hakikati, 1984 isimli distopyasında ne güzel de ifade etmiştir: "İnsanlar hürriyet ile mutluluk arasında seçim yapmak zorundaydı ve büyük çoğunluk mutluluğu seçiyordu”. Bkz. George Orwell, 1984, Çev. Celal Üster, 68. Bs., Can Yayınları, İstanbul 2019, s. 283.

134 Hayek, Kölelik Yolu, s. 105. Hayek, bireyin ve onun mülkiyetinin devletin belli amaçları için kullanılmasına yol açacak kadar yetkili bir parlamento kanununun, bir diktatörün kanunu kadar keyfi olabileceğini belirtir. Bkz. Hayek, Liberalizm, s. 56 . 
Planlamacılıkta amaçlara ulaşabilmek için parlamento kapsamı ve amaçları belli olmadan yürütme organına yetki verirse ve yasama organının yetkisi ancak yürütmenin işlemlerini toptan kabul ya da reddetmekten ibaretse; bu yetki devri ile yönetim yasama organından çıkmış demektir ${ }^{135}$. Bu durumda parlamento yalnızca yetkiyi kullanabilecek kişileri seçer. Hayek’e göre bu durum "plebisitli diktatörlüğe" dönüşür. Hükümet başkanı dilediği zaman halk oyuna gidebilir ve kendi mevkiini koruyarak dilediği yönde oy alabilme gücüne de sahip olur ${ }^{136}$.

Yetkilerinin sınırı olmayan bir yönetimden ekonomiyi tamamen tasarlanmasını ve yeniden dağıtımı tesis etmesini beklemek masum görünen amaçlardan çok başka sonuçlara yol açar. İktidarın herkesçe kabul edilen bir ihtiyaç hiyerarşisi ve ahlak sistemi kurması pek kolay değildir. Bu nedenledir ki herkesin temel prensiplere/ideolojilere inanması planlamacilık için önemlidir. Gerekli olan inanç ve güvenin sağlanabilmesi için de resmi görüşün topluma duyurulması ve kabul ettirilmesi gerekir. Bu nedenle de Hayek'in tespit ettiği üzere ilk olarak sosyalistler tarafından propaganda araçları bulunmuştur ${ }^{137}$. Bireylerin hayatlarının tüm alanlarına tesir etmek ve her konuda partinin görüşlerinin bireylere kabul ettirilmesini sağlamak adına, bu araçları kullananlar, yani özel selamlama şekilleri belirleyenler, çocukların daha küçük yaşta parti görüşleri doğrultusunda yetiştirilmesini sağlayanlar, partiye bağlı spor kulüpleri kuranlar, spor müsabakaları yapanlar, hücre teşkilatlarıyla özel hayatı tamamen kontrol ve gözetim altında tutanlar sosyalistler olmuştur. Ancak özellikle Naziler ve faşistler tarafından bu araçlar yoğun bir şekilde kullanılmıştır ${ }^{138}$.

Planlanmış toplumlarda plan adına yapılanlar, tek bir hedefe tüm toplumun adeta zorla veya manipülasyonlarla yönlendirilmesine neden olur. Hayek savaş şartlarında dahi kabul edilemeyecek bazı eylemlerin kolektivist toplumlarda amaçiçin meşru ve ahlaki olarak "iyi” görülebileceğini belirtir. Çünkü amaç için bireysel hakların sınırlandırılmasının bir sınırı yoktur ${ }^{139}$. Nazi Almanyasında olduğu gibi Gestapo, SS’ler ${ }^{140}$ veya propaganda bakanlığı; faşist İtalya'daki veya Nazi Almanyassındaki kamu ajanları insani duygulara değil, ancak kolektivist duygulara uygunluğun isimleridir. Bu insani olmayan duygulara yatkınlık da yükselmenin ve saygı görmenin kapılarını aralar ${ }^{141}$.

Öte yandan kolektivist bir toplumda, ayrıca bireyin tercih yapma bilinci de bozulur. Kişilerin bireysel sorumluluktan kurtarılması idealine dayanan kolektif yaşam anlayışı, çoğunluğa rağmen doğru

135 Hayek, Kölelik Yolu, s. 103; Ayrıca bkz. Hayek, Liberalizm, s. 61.

136 Hayek, Kölelik Yolu, s. 103.

$137 \mathrm{Bu}$ araçları ilk bulan ve kullananların sosyalistler olduğunu ifade eder. Bkz. Hayek, Kölelik Yolu, s. 161.

138 Hayek, Kölelik Yolu, s. 160-161. Örneğin bugün Küba’da da Genç Komünistler Birliği (The Union of Young Communist) adlı gençlik örgütü, gençlerin sosyalist ideoloji etrafında birleştirilmesini ve eğitilmesini sağlama amacına hizmet etmektedir (Küba Cumhuriyeti Anayasası, md. 6). Bkz. Buna ilişkin bir örnek için bkz. http://www.uci.cu/en/university/ news/young-communists-union-known-ujc-launches-national-anniversary-campaign-organization, (24.05.2020); Bkz. Keskin, s. 47.

139 Hayek, Kölelik Yolu, s. 199.

140 Gestapo, hiçbiri hukuki sınırı olmayan, siyasi rakipleri ve Nazi rejiminin polisine boyun eğmeyi reddedenleri tespit edip tutuklamak için acımasız yöntemler kullanan Nazi polis (gizli) servisi. Bkz. https:/encyclopedia.ushmm.org/content/ tr/article/gestapo, (24.05.2020). SS üyeleri, yardımcı polis gücü ve daha sonraları toplama kampı muhafızları olarak da hizmet gören Nazi birliği. Bkz. https://encyclopedia.ushmm.org/content/tr/article/ss-police-state, (24.05.2020).

141 Hayek, Kölelik Yolu, s. 200. 
bildiğini savunma, bireysel otonomi, gönüllü iş birliği ve özgüven gibi erdemleri ortadan kaldırır. Bunun yerine de ancak koşulsuz itaat fikrini koyar ${ }^{142}$.

Esası bireylerin toplum içerisinde eritilmesi idealine ve hayatın tüm alanlarını insanlar adeta robotmuşçasına üstün aklın çıkarımına dayalı olarak tasarlamaya bağlı olan planlamacılığın en büyük düşmanı da hürriyet ruhu ve bunu korumaya hizmet eden hukukun üstünlügüdür. Planlamacılık taraftarlarının bu tehditleri bertaraf edebilmesinin ancak, Almanya’da olduğu gibi sürece yayılmış ve sindirmeye dayalı bir toplum mühendisliğiyle başarılabileceğini belirtmek gerekir ${ }^{143}$. Zira sosyal konum ve rütbelere ancak devletin maaşlı memuru olmakla ulaşılabiliyorsa, devlet kademesinde olmayan işler hoş görülmüyor adeta aşağılanıyorsa, çoğunluk hür olmayı değil, güvenliği, eşitliği seçecektir. Hayek’e göre eşitliğin ve güvenliğin tercih edildiği bir toplumda da hürriyet idealini takip edecek pek fazla kimse yoktur ${ }^{144}$. Düşünür ekonomik güvenliğin, gelirlerin garanti edilmesi ve ticari risklerden korunma gibi planlamayla sağlanan güvencelerin, özgürlük pahasına tesis edilmesini kışla düzenine benzetir. Kışlada kıtlık olması halinde herkesin tayını azaltılır, ancak bolluk halinde herkese belli bir tayın ve bazı imkanlar tesis edilir. Bu durum ona göre, hiyerarşik yaşamı ve hürriyetler üzerindeki kısıtlamaları kaçınılmaz kılar ${ }^{145}$.

Planlamacılığın hâkim olduğu bir toplumda hukuk ve ahlak idealinin korunması düşüncesinin feda edilmesi kaçınılmazdır. Liberal bireyci ahlak anlayışında ise, Hayek’e göre, günah günahtır ${ }^{146}$. Yani amacımız iyi olsa bile ve hatta sonucunda bir zarar doğmamış olsa da rüşvet, işkence, iftira vb. eylemler kötüdür. Bu ahlaki ilkeler ve yasaklar eylemin amacına bakılmaksızın yasak olarak kabul edilmektir. Oysa, Hayek'e göre kolektivist toplumlarda aslolan toplumun iyiliği ve menfaatidir. Önemli olan eylemin amacı, yani toplumdur. Bu nedenle yapılan eylemin iyiliği amaca uygunlukla ölçülür. Dolayısıyla, örneğin, insan vicdanıyla (ve hukukun temel ilkeleriyle) bağdaşmasa bile üstlerinin emirlerini uygulamak zorunludur ${ }^{147}$.

Hayek bu tespitleriyle bir gücü sınırlayamazsak, o gücün kötüye kullanılmasını da önleyemeyeceğimiz gerçeğini açıklamaya çalışır ${ }^{148}$. Çünkü o demokrasiye de güvenmez. Neticede hürriyetin emniyetini tamamen demokrasiye birakmaz. Ona göre hürriyetin demokrasiye emanet edildiği durumlarda kimilerinin hürriyetleri kimilerinin tercihlerine kurban edilebilir. Örneğin çoğunluğun uzlaşmasıyla

142 Hayek, Kölelik Yolu, s. 263-264. 1984 romanının baş kahramanı Winston’ın ifadesiyle; "Bilinçleninceye kadar asla başkaldıramayacaklar, ama başkaldırmadıkça da bilinçlenemezler”. Bkz. Orwell, s. 81.

143 Hayek, Kölelik Yolu, s. 181.

144 Hayek, Kölelik Yolu, s. 181.

145 Hayek, Kölelik Yolu, s. 176. Mal ve hizmetlerin merkezi otorite tarafından dağıtılmasını sağlayacak ve herkesin neye ne kadar sahip olması gerektiğini tespit edecek objektif kurallar yoktur. Ancak mal ve hizmetlerin tek bir merkezden belirlenmesi, herkesin önceden belirlenen tek bir amaca sevk edilmesiyle mümkündür. Bireyler kendi amaçlarını değil, kendilerine yüklenen görevleri gerçekleştirmek zorunda kalır. Bu, ancak toplumun ordu gibi kapalı bir yapı olarak görülmesi halinde mümkün olabilir. Bkz. Hayek, Liberal Bir Sosyal Düzenin İlkeleri, s. 100-101.

146 Hayek, Kölelik Yolu, s. 196.

147 Hayek, Kölelik Yolu, s. 196.

148 Bkz. Hayek, Kölelik Yolu, s. 285. Demokrasi ile liberalizm, ve dolayısıyla hukukun üstünlüğü, her zaman uyumlu değildir. Zira demokrasi siyasi iktidarın sınırlandırılmasını gerektirmez. Bazen ise liberal ilkelere yer verilmiş olabilir. Ancak liberalizm, demokrasinin aksine iktidarın kaynağını değil, tamamen sınırlandırılmasını gerektirir. Bkz. Hayek, Liberal Bir Sosyal Düzenin İlkeleri, s. 82 . 
tercihler ortaya çıkmışsa bu durumda bir grup azınlığın o tercihlere uyması için zorlanması gerekir. Hayek bu hususta, iktidarı keyfi hareket etmekten alıkoyanın onun kaynağı değil, "belirlenmiş hukuki sınırların" olduğunu belirtir ${ }^{149}$. Demokratik takip ve denetim, seçmenlerin seçim zamanı sandıkta iktidara hesap sorması gibi yollarla iktidarı sınırlayabilir, ancak bu yeterli değildir. Ona göre, çoğunluğa dayanan iktidarın keyfileşemeyeceğinin dayanağı yoktur. İktidarın bazı kurallarla sınırlanması gerekir. Aksi halde yetkilerin kurallara bağlanmaksızın kullanılması söz konusu olursa, tıpkı diktatör rejimi gibi, demokratik bir iktidar da keyfi bir hale gelir ${ }^{150}$.

Nihayet Hayek hukukun yönetimi yerine kontrollü bir sosyal yaşam, planlanmış ekonomik hayat idealinin ve dolayısıyla kolektivizmin ancak çıkar birliğinin olduğu ırkçılık, milliyetçilik, sınıfçılık gibi görünümlerle varlık kazandığını savunur. Çünkü ancak bu tür hedefler yığınlar üzerinde bir amaç ve menfaat birliği sağlayabilir ${ }^{151}$.

Bireyin hürriyetinin korunması açısından diğer bir konu da ahlak konusudur. Hayek’e göre tasarlanmamış bir toplumda ahlak bireysel temele dayanır. Dolayısıyla bireyin özgürlüğüne müdahale edilmediği zaman bireyin kendi şahsi menfaatleri kadar toplumun menfaatlerini de korumak adına kendiliğinden-gönüllüğe dayanan ahlak anlayışı, eşitsizlik adına girişilen çabalar ve planlamacılıkla tehdit edilir ${ }^{152}$. Hayek’e göre kişinin eylemlerinin ahlakiliği ancak o eylemlere hür iradesiyle karar verme imkânı verildiğinde değerlendirilebilir. Yani ancak hür birey kendiliğinden bazı menfaatlerini feda etmeyi göze almışsa onun eylemlerinin ahlakiliği tartışılabilir. Düşünür bu bağlamda iyilik yapmaya zorlayan bir sosyal yapının ahlakiliğinden söz edilemeyeceğini vurgular ${ }^{153}$. Ahlaki ve ekonomik hemen her alanda müdahale edilmesi de toplumsal ahengi bozar. Hayek'e göre piyasanın kendiliğinden oluşan düzeni ve seyri bozulduğu zaman bir grup insanın düzeni sağlamasından başka

149 Hayek, Kölelik Yolu, s. 105-106. Demokrasi iktidarın kaynağını konu edinirken, liberalizm iktidarın sınırlandırılmasını, dolayısıyla iktidar çoğunluk olsa da onun hukuk eliyle sınırlandırılmasını konu ve amaç edinir. Bkz. Hayek, Liberalizm, s. 67-68.

150 Hayek, Kölelik Yolu, s. 105-106. Parlamentonun kanunları da bireyi ve onun mülkiyetini devletin amaçları için araç haline getiriyorsa, tıpkı bir diktatörün kanunları gibi keyfi olarak değerlendirilebilir. Bkz. Hayek, Liberalizm, s. 56. Hayek, aslında planlamacılığın kaçınılmaz olarak diktatörlüğe yol açtığını vurgular. Her ne kadar demokratik araçlar planlamacılığın benimsendiği toplumlarda görülebilse de bu siyasi iktidarın sınırlarının ve bireyin korunduğunu göstermez. Düşünüre göre aslolan bireydir. Bu nedenle bireysel hürriyetlerin ve bireysel gelişmelerin korunması gerekir. Bunun sağlanabilmesi için de toplum düzenine, ekonomiye ve sosyal yaşama müdahale edilmemeli ve kontrol altına alınmamalıdır. Zira görüldüğü üzere "planlamaya yönelik yetkiler yalnızca ekonominin tasarlanması sonucuna yol açmaz".

151 Hayek, Kölelik Yolu, s. 189. Ayrıca Birinci Dünya Savaşından, İkinci Dünya Savaşına kadar geçen süreç göstermiştir ki ekonomik krizler ve işsizlik gibi ekonomik sorunlar devlet müdahalesine talebi artırmış ve milliyetçiliğin şahlanmasına neden olmuştur. Bu gelişim ise bürokrasinin genişlemesine ve keyfi yönetimin doğmasına yol açmıştır. Bkz. Hayek, Liberalizm, s. 49.

152 Hayek, Kölelik Yolu, s. 262. Bireyler kendi amaçlarını takip ettikleri zaman bu piyasada serbest bilgi akışının oluşmasını da sağlar. Bireyler bu yönde eylemlerini bencilce ya da fedakârca gerçekleştirse bile, onların amaçlarını takip etmeleri bilgilerin kendiliğinden piyasaya girmesini sağlar ve bu bilgi akışı, Hayek’e göre hiçbir planlayıcının kontrol edemeyeceği kadar, bilgilerin başarılı kullanılmasını sağlar. Bkz. Hayek, Liberalizm, s. 58.

153 Hayek, Kölelik Yolu, s. 262-263. Ahlakın konusu bilinçli insan davranışlarıdır. Kişilerin kendi iradeleriyle gerçekleştirmedikleri davranışlar ahlaka konu edilemez. Ayrıca bkz. Saniye Vatandaş, "Felsefenin Kadim Bir Konusu Olarak Ahlâk ve Ahlaki Eylemin Amacı Olarak "Mutluluk"”, Uluslararası Yönetim ve Sosyal Araştırmalar Dergisi, C. 4, S. 7, Y. 2017, s. 2. 
bir seçenek yoktur. O nedenledir ki kendiliğinden düzeni yıkanlar, istemeseler de tüm kontrolün bir grubun eline geçmesine neden olur ${ }^{154}$.

Bununla birlikte Hayek kişilerin arasındaki fırsat eşitsizliklerinin kimsenin zorlanamayacağı veya başkalarının iradesine bağlanmayacağı şekilde azaltılması gerektiğini reddetmez. Kendiliğinden oluşan düzeni bozmadan bazı durumlarda firsat eşitsizlikleri önlenebilir ${ }^{155}$. Ancak fırsat eşitliği adına bireysel hürriyetler ortadan kaldırılıyorsa ve tasarlanmamış düzen kontrol altına alınmaya başlanıyorsa bu hürriyet ruhuyla uyumlu değildir. Bireysel hürriyet, tüm toplumun tek bir hedefe sevk edilmesiyle bağdaştırılamaz. Hayek ancak savaş ve bazı felaket hallerinde kimi ortak hedeflerin varlığının kabul edilebileceğini belirtir. Düşünüre göre bu fedakârlık ise hürriyetimizin korunabilmesi için gereken bir bedel, diğer bir ifadeyle maliyettir ${ }^{156}$. Zira savaş ve bazı tabiat olayları hürriyetlerimizin tamamen anlamsız kalmasına ve ortadan kalkmasına yol açabilir. Bu nedenle kimi durumlarda, bunlar olağanüstü durumlardır, devletin kontrolünden ve ortak hedeflerin takip edilmesinden söz edilebilir. Fakat bu istisnadır.

Hayek'e göre tek ilerici politika bireyin hürriyeti politikasıdır ${ }^{157}$. İktisadi faaliyetler iktidarın siyaseti dışındaki amaçlarla yürütülebiliyor ve iktidardan ayrı olarak yönlendirilebiliyor olması, hür bir toplumla hür olmayan toplum arasındaki, diğer ifadeyle liberal ve totaliter rejimler arasındaki farkı ortaya koyar $^{158}$. Hür toplum adına bu farkın emniyeti ise hukukun üstünlüğüyle sağlanabilir. Hayek'e göre hukukun üstünlügü ister anayasayla veya bildirilerle ister gelenekle olsun yasama organı dahil devlet organlarının sınırlandırılmasını, bireyin vazgeçilmez bazı haklarının tanınmasını ve insan haklarının dokunulmazlı̆̆ını kapsar ${ }^{159}$.

\section{SONUÇ}

Hayek’te, iktisadi hürriyetler ve dolayısıyla tercih hürriyeti tüm hürriyetlerin ve insani gelişmelerin temelini oluşturur. Bu hürriyetlere müdahale ise yalnızca iktisadi konularla sınırlı değildir. Zira kişinin hayatında iktisadi olmayan konu yoktur. Dolayısıyla devlet eliyle planlamanın sağlanması bireyin tüm özerk alanına yöneliktir. Bu tarz bir planlama girişimi de Hayek’e göre eninde sonunda sınırsız iktidara ve ayrıcalıklı bir kesime yol açarken; bireyi de toplum adına köleleștirir. Bireyi toplumsal amaçlar için araç konumuna indirir.

154 Hayek, Kölelik Yolu, s. 250.

155 Hayek, Kölelik Yolu, s. 146. Devletin kimi önlemleri alması veya müdahaleleri, kendiliğinden düzeni bozacak nitelikte olmamalıdır. Bkz. Yayla, Hayek'in Fikir Dünyasında Liberalizm, s. 20. Ayrıca devletten beklenen “eşit hürriyeti” sağlaması ve bireysel girişimlerin önüne çıkan insan kaynaklı engelleri ortadan kaldırmasıdır. Bu hususta bkz. Hayek, Liberalizm, s. 54.

156 Hayek, Kölelik Yolu, s. 257. Devletin müdahale edebileceği durumlar ve müdahalenin sınırları için bkz. Bkz. Yayla, Hayek'in Fikir Dünyasında Liberalizm, s. 20.

157 Hayek, Kölelik Yolu, s. 288.

158 Benzer yönde bkz. Hayek, Kölelik Yolu, s. 154.

159 Hayek, Kölelik Yolu, s. 123. Her kanunun hürriyetleri korumaya yönelik olmadı̆̆ına, ancak kimi niteliklere sahip kanunların bunu sağlayabileceğine yönelik değerlendirmeler için ayrıca bkz. Hayek, Liberalizm, s. 55. 
Bugün ekonominin merkezi olarak planlandığını varsaydığımızda, televizyon, gazete, sosyal medya platformları, radyolar, ulaşım araçları ve konak yerleri ve benzer diğer tüm ekonomik değeri olan unsurlar da planlamanın konusu haline gelir. Bu da, bireyin sosyal ve özerk alanına dahil gördüğümüz tüm mekan ve araçların kamusallaştırılmasına neden olur. Örneğin, mitinge gitmek isteyen bir öğrenci, sosyal medyada ekonomi yönetimini eleştiren ekonomist veya kitap yazmak isteyen yazar, böyle bir toplumda hür bir şekilde isteğini yerine getiremez. Serbest piyasanın hâkim olduğu kimi toplumlarda dahi muhalefetin, aykırı sesin; kişilerin bizzat veya medya patronları ile diğer sermayedarların tehdit edilmesiyle kontrol altında tutulduğunu görmekteyiz. Kâğıdı üreten, otobüslere ve yollara sahip olan, televizyon ve sosyal medya platformlarını kontrol eden bir devletin, muhalefeti veya farklı düşünenleri susturmayacağını nasıl temin edebiliriz? Bununla birlikte, tüm araçları kontrol eden devlet olunca, tek yanlı bir propaganda yapılmayacağını kim iddia edebilir?

Bireylerin kendi planlarını icra edemediği, geleceğine ilişkin tercihte bulunamadığı ya da dilediği şekilde haber alamadığı ve serbestçe iletişim kuramadığı bir toplumda "hür bireylerden" değil, "köleleştirilmiş insanlardan" bahsetmek gerekir. Bu, demokrasi için de büyük bir tehlikedir. Kimi teorisyenler, demokrasiyi yalnızca çoğunluğun iradesi olarak gördüğünden, çoğunluk tarafından kabul edilen planlamacılığı reddetmeyebilir. Ancak planlama mekanizmasının, zaman içerisinde bir menfaat grubunun eline geçmesi ve siyasi iktidar olarak plan yapanların keyfileşmesinin kaçınılmaz olması gösterir ki, enin de sonunda siyasi rekabet ve serbest demokratik yarış ortadan kalkar. Kolektif amaçlar dışındaki amaçları hedefleyen, planın dışına çıkan herkes rejim için tehdit görülür ve hain olarak adlandırılır. Yine tarihi tecrübeler de bunu göstermektedir. Totaliterleşen her rejim, kendi baskı düzenini korumak için propaganda araçları geliştirerek bireylerin zihinlerine dahi girmeyi amaçlarken, diğer yanda da dost-düşman, hain-vatansever gibi çeşitli ayrımlar yaparak toplumu bölmeyi ve bu şekilde rejim taraftarlarının sistemi sorgulamasını önlemek ister. Diğer bir ifadeyle, vatanı ve kutsal idealleri için ölmeye hazır, ancak düşünmekten mahrum bir kitle ortaya çıkar.

Hayek de yaşadığı dönem itibariyle sosyal adalet ve eşitlik gibi pek çok kişinin kolaylıkla kabul edebileceği amaçlarla ekonominin planlanmasına yönelik eğilimlerin ortaya çıkmasını, tüm bu sebeplerle eleştirir. Kuşkusuz Hayek, bu konuda haklıdır. Zira ekonomik değeri haiz unsurların merkezileştirilmesi ile sınıfçılık, aşırı milliyetçilik ve buna benzer birey onuru ile toplumsal barışı dışlayan çeşitli idealler aynı araçlara sahiptir. Araç birlikteliği ise, zamanla oluşan seçkin-menfaat grubunun kendi idealleri adına hareket etmesine yol açar. En azından bunu engelleyecek bir hukuk düzeni ortadan kalkar. Bu şartlarda iddia edildiği gibi ne eşitlik kalır ne de sosyal adaletin sağlanması. Ortaya çıkan sonuç yalnızca devletin tüm imkanlarına sahip bir parti örgütü ve bu örgüte bağlı bürokrasiden başka bir şey olamaz.

Böyle bir yeni sınıfın oluşması da toplumu oluşturan diğer kişilerin, devlet imkanlarından eşit bir şekilde faydalanmak ya da muhalefet olmanın dezavantajından kurtulmak için "asalaklaşmasına" yol açar. Liyakatin değil, nepotizmin olduğu her toplumun varacağı nokta budur. Partili olmanın, bir parti üyesinin yakını olmanın ya da rejime sadık olduğunu çeşitli faaliyetlere katılarak göstermenin saygınlık ve menfaat getirdiği bir toplumda, ancak her şeye rağmen ahlaki davranabilenler hariç, 
hemen herkesin "çalışmak" yerine "sadakat gösterme" yoluna gideceğini söylemek abartı olmasa gerek.

Ayrıca burada belirtilmesi gereken diğer husus Hayek'in hukukun üstünlüğü yaklaşımının yalnızca şekli nitelikte olmadığıdır. Zira Hayek, kuralların genelliğini ve belirliliğini hürriyet rejiminin korunması adına gerekli görmekte, öte yandan da hukukun üstünlüğünün çeşitli hukuki belgelerle insan haklarının korunması anlamına geldiğini belirtmektedir. Kanaatimizce Hayek'in hukukun üstünlüğü anlayışı, hürriyeti tehdit eden bir yaklaşımla, kuralla ve düzenle bağdaşır nitelikte değildir. Nitekim genel ve soyut kuralların içeriği, hürriyetlere aykırı ve kolektivist amaçlara sahip olabilir. Yine Hayek'in planlamacılığa karşı duruşu ve yasama organının yürütmeye geniş ölçekte yetki devri yapmasına karşı çıkması da, hukukun üstünlüğünün yasama organı tarafından yalnızca genel ve soyut kural konulması anlamına gelemeyeceğini gösterir niteliktedir. Kuşkusuz buna/ bunlara en iyi örnek Nazi Almanya’sıdır. Dönemin koşullarında Nazi görevlilerin eylemleri, kimi zaman katliamdan sonra yürürlüğe giren bir kanunla; kimi zaman ise ilan edilmeyen ve "gizli" adıyla yalnızca söz konusu görevi ifa edecek memura iletilen düzenleyici işlemlerle hukukileştirilmeye ve meşrulaştırılmaya çalışılmıştır.

Neticede Hayek'in hukukun üstünlügü anlayışının siyasi iktidar ve devlet organlarının hukukla sınırlılığını, kuralların konulmasının ve kuralların belirli nitelikleri haiz olması ve özellikle bireysel hürriyetlerin muhafazasını kapsadığını ifade etmek gerekir. Hayek bu görüşlerini planlamacılık tehlikesi bağlamında ele almaktadır. Burada onun tehlike olarak işaret ettiği ise yalnızca kolektif toplumun amaçları değildir. Zira bu amaçlar çoğu kişinin kabul edebileceği nitelikte olabilir. Ancak burada tehlike, iktisadi hayatı ve hürriyetleri kontrol eden iktidarın hürriyetler üzerinde tahakküm kurmasıdır. Hayek, bu bağlamda hürriyet rejiminin önemine dikkat çekerek, tercih hürriyeti ile iktisadi hürriyetlerin tüm diğer hürriyetlerin temelini oluşturduğunu; bireysel alanların özerk kalması ve kamusallaşmaması gerektiğini belirtir.

Bizim de bugün "hürriyet rejimi ve hukukun üstünlügü̈" adına dikkatli olmamız gerekir. Bunun için kanunların genel ve soyut olmak gibi diğer nitelikleri haiz olmasını ve hürriyet rejimini dışlamamasını, yargı bağımsızlığı ve kuvvetler ayrıllğ̆ gibi ilke ve kurumları temin etmemiz gerekir. Sınıf̧ıılık, particilik gibi bireyi dışlayan, sosyal adalet ve eşitlik söylemi adı altında ileri sürülen yaklaşım ve ideallere karşı dikkatli olunması, herhangi bir menfaat karşısında hürriyetlerin ve bireylerin araçsallaştırılmaması gerekir. Aksi halde, böyle bir kapının aralanması demek, engellenemez bir "köleleşme" kapısının da aralanması demektir.

\section{KAYNAKÇA}

AKTAŞ, Sururi, “Hukuk Devleti İdealine Felsefi Bir Bakış”, YBHD, Sayı 2020/1. (ss. 1-32).

AKTAŞ, Sururi, Hayek'in Hukuk ve Adalet Teorisi, 2. Bs., Liberte Yayınları, Ankara 2018.

AKTAŞ, Sururi, Prosedürel Doğal Hukuk-Lon L. Fuller’in Hukuk Kavramı, 1. Bs., On İki Levha Yayıncılık, İstanbul 2010.

BOUDREAUX, Donald J., Yeni Başlayanlar İçin Hayek, Çev. İlkay Yılmaz, Liber Plus Yayınları, İstanbul 2017.

BUTLER, Eamonn, Hayek, Çev. Yusuf Ziya Çelikkaya, 2. Bs., Liberte Yayınları, Ankara 2001. 
BUTLER, Eamonn, Özgür Toplumun Temelleri, Çev. Hakan Şahin, 1. Bs., Liberte Yayınları, Ankara 2016.

ERDOĞAN, Mustafa, Anayasal Demokrasi, 13. Bs., Siyasal Kitabevi, Ankara 2017.

FULLER, Lon L., Hukukun Ahlakı, Çev. Engin Arıkan, 1. Bs., Tekin Yayınevi, İstanbul 2016.

GORODNICHENKO, Yuriy/ROLAND, Gerard, "Understanding the Individualism-Collectivism Cleavage and Its Effect: Lessons from Culturel Psycgology”, IEA Conference Volume Series (İçinde), C. 150, Y. 2012, https://eml.berkeley.edu/ groland/pubs/IEA\%20papervf.pdf (E. 21.09.2020).

GÜNEŞ, Turan, Türk Pozitif Hukukunda Yürütme Organının Düzenleyici İşlemleri, 1. bs., Sevinç Matbaası, Ankara 1965.

HAMOWY, Ronald, “Friedrich A. Hayek”, Çev. Atilla Yayla, Hayek’in Liberalizm Anlayışı (İçinde), 1. Bs., Kesit Yayınları, İstanbul 2012.

HAYEK, Friedrich A., "Liberal Bir Devletin Anayasası”, Çev. Mustafa Erdoğan, Hayek'in Liberalizm Anlayışı (İçinde), 1. Bs., Kesit Yayınları, İstanbul 2012.

HAYEK, Friedrich A., "Liberal Bir Sosyal Düzenin İlkeleri”, Hayek’in Liberalizm Anlayışı (İçinde), 1. Bs., Kesit Yayınları, İstanbul 2012.

HAYEK, Friedrich A., "Liberalizm”, Çev. Ünsal Çetin, Hayek'in Liberalizm Anlayışı (İçinde), 1. Bs., Kesit Yayınları, İstanbul 2012.

HAYEK, Friedrich A., "The Fatal Conceit - The Errors of Socialism”, The Collected Works of Friedrich August Hayek, V. I, Ed. W. W. Bartley, Routledge, London, 1998.

HAYEK, Friedrich A., Hukuk, Yasama ve Özgürlük - Özgür Bir Toplumun Siyasi Düzeni, Çev. Mehmet Öz, Türkiye İş Bakası Kültür Yayınları, İstanbul 1997.

HAYEK, Friedrich A., Kanun, Yasama Faaliyeti ve Özgürlük-Kurallar ve Düzen, Çev. Atilla Yayla, Türkiye İş Bankası Kültür Yayınları, İstanbul 1994.

HAYEK, Friedrich A., The Constitution of Liberty, The University of Chicago Press, 1978.

HAYEK, Friedrich A., The Road to Serfdom, Routledge, London/New York 2006.

HAYEK, Friedrich v., Individualism and Economic Order, 3. Bs., The University of Chicago Press, Chicago 1958.

HAYEK, Friedrich v., Kölelik Yolu, Çev. Turhan Feyzioğlu/Yıldıray Arsan/Atilla Yayla, 6. Bs., Liberte Yayınları, Ankara 2015.

HAYEK, Friedrich v., Özgürlüğün Anayasası, Çev. Yusuf Ziya Çelikkaya, Bigbang Yayınları, Ankara 2013.

HEYWOOD, Andrew, Siyaset Teorisine Giriş, Çev. Hızır Murat Köse, 8. Bs., Küre Yayınları, İstanbul 2017.

HUBER, Ernst Rudolf, “Modern Endüstri Toplumunda Hukuk Devleti ve Sosyal Devlet”, Çev. Tuğrul Ansay, Ankara Üniversitesi Hukuk Fakültesi Dergisi, C. 27, S. 3, Y. 1970. (ss. 27-51).

İşSEVENLER, Vahdet, "Hukukun Erdemi ve Fuller'in Ahlakları", İÜHFM, C. LXXIV, S. 2, Y. 2016. (ss. 573587).

KESKİN, Erdoğan, Anayasa Hukukunda Anayasacılık Düşüncesi, Adalet Yayınevi, Ankara 2020.

KÖKÜSARI, İsmail, Anayasa Hukukunda Hukukî Güvenlik İlkesi, Adalet Yayınevi, Ankara 2015.

LOUGHLIN, Martin, Foundations of Public Law, 1. Bs., Oxford University Press, Chennai 2010.

MARTIN, Brian, "Power Tends to Corrupt", Philosophy and Social Action, C. 16, S. 3, Y. 1990.

ORWELL, George, 1984, Çev. Celal Üster, 68. Bs., Can Yayınları, İstanbul 2019.

ÖZKAN, Ahmet Fatih, "Ekonomik Kamu Düzeni ve Ekonomik Kolluk Faaliyeti”, Ankara Barosu Dergisi, S. 4, Y. 2009 (Güz). (ss 75-94).

PRICE, Roger, 1848 Devrimleri, Çev. Nail Kantemir, Babil Yayınları, İstanbul 2000.

RIJPKEMA, Peter, “The Rule Of Law Beyond Thick and Thin”, Law and Philosophy, S. 32, Y. 2013. 
SOYAK, Alkan, “Türkiye’de İktisadi Planlama: DPT’ye ihtiyaç Var mı?”, Doğuş Üniversitesi Dergisi, C. 4, S. 2, Y. 2003. (ss. 167-182) .

TOPSES, Gürsen, "Elseverlik (Alturizm) ve Benseverlik (Egoizm) Ölçeğiyle İlgili Geçerlik ve Güvenirlik Çalışması", International Journal of New Trends in Arts, Sports \& Science Education, Y. 2012, C. 1, S. 2. (ss. 60-71).

UYGUN, Oktay, Hukuk Teorileri, On İki Levha Yayıncılık, İstanbul 2017.

VATANDAŞ, Saniye, "Felsefenin Kadim Bir Konusu Olarak Ahlâk ve Ahlaki Eylemin Amacı Olarak "Mutluluk”", Uluslararası Yönetim ve Sosyal Araştırmalar Dergisi, C. 4, S. 7, Y. 2017. (ss. 1-9).

WEBER, Max, Bürokrasi ve Otorite, Çev. H. Bahadır Akın, 8. Bs., Liberte Yayınları, Ankara 2017.

YAYLA, Atilla, "Hayek'in Fikir Dünyasında Liberalizm”, Hayek’in Liberalizm Anlayışı (İçinde), 1. Bs., Kesit Yayınları, İstanbul 2012.

YAYLA, Atilla, Özgürlük Yolu, Profil Yayıncılık, İstanbul 2014.

YILMAZ, Cevdet, “Piyasa Ekonomilerinde Ulusal Planlama ve Çeşitli Planlama Yaklaşımları”, Amme İdaresi Dergisi, C. 32, S. 1, Y. 1999. (ss 85-101).

\section{internet Bağlantıları}

http://www.uci.cu/en/university/news/young-communists-union-known-ujc-launches-national-anniversarycampaign-organization, (24.05.2020).

https://encyclopedia.ushmm.org/content/tr/article/gestapo, (24.05.2020).

https://encyclopedia.ushmm.org/content/tr/article/ss-police-state, (24.05.2020).

https://sozluk.gov.tr (14.05.2020).

https://www.dictionary.com/browse/bill-of-attainder, (24.05.2020).

https://www.phrases.org.uk/meanings/absolute-power-corrupts-absolutely.html (E. 16.04.2019). 